九州大学学術情報リポジトリ

Kyushu University Institutional Repository

\title{
A Systematic Study of the Japanese Pipunculidae (Diptera) : Part I. Introduction to the Family and the Genus Verrodlia Mik
}

Morakote, Rut

Entomological Laboratory, Faculty of Agriculture, Kyushu University

Hirashima, Yoshihiro

Entomological Laboratory, Faculty of Agriculture, Kyushu University

https://doi.org/10.5109/23895

出版情報: 九州大学大学院農学研究院紀要. 34 (3)，pp.123-159，1990-02. Kyushu University バージョン：

権利関係 : 


\title{
A Systematic Study of the Japanese Pipunculidae (Diptera) Part I. Introduction to the Family and the Genus Verrallia Mik
}

\author{
Rut Morakote and Yoshihiro Hirashima \\ Entomological Laboratory, Faculty of Agriculture, \\ Kyushu University, Fukuoka 812, Japan
}

(Received March 31, 1989)

\begin{abstract}
A classification of the family Pipunculidae of Japan is presented for the first time based on the examination of about 2,000 Japanese pipunculid specimens. It was revealed that the Japanese fauna is composed of 3 subfamilies, 8 genera and 108 species. One genus and twenty four species are newly recorded from Japan, and sixty two species are described as new to science. In this paper (Part I ) historical review of works of this family in Japan, morphology and terminology of adults, and a key to subfamilies, tribes and genera as well as biological data of found species are given. Besides, eight species of the genus Verrallia Mik are treated, with key to species and illustrations of their important diagnostic characters. Three of them are new species and four of them are new to Japan.
\end{abstract}

\section{INTRODUCTION}

Up to present about 600-700 described species of pipunculid flies have been recorded from all over the world. In Japan, so far as we know, only '22 species have been known.

The interests in pipunculid flies in Japan was begun when Esaki and Hashimoto (1932) recorded a fly as the parasite of the rice green leafhopper, Nephotettix cincticeps (Uhler), a serious pest of rice in Japan. They reported that the percentage parasitism of this fly was as high as $65 \%$ in 1936. Thereafter many informations have been accumulated on the Japanese pipunculid flies inhabiting paddy fields. Unfortunately, however, studies on the flies inhabiting general vegetations have been rather neglected. The present study on the Japanese pipunculid flies was undertaken in order to improve this condition.

This study was begun by the first author, Rut Morakote, for his doctoral thesis in 1983 and was completed by the spring of 1989. As the result of his study, the Japanese Pipunculidae are revealed to comprise 108 species. Sixty two species of them are new species and 25 species are new to Japan.

The results of the present study will be published in six parts. In the first part of this study are given the morphology, terminology, historical review, and a key to subfamilies, tribes and genera in addition to the review of the genus Verrallia Mik of Japan. The latter includes 8 species, 3 of them are new and 4 of them are new to Japan.

*Contribution from the Entomological Laboratory, Faculty of Agriculture, Kyushu University, Fukuoka (Ser. 3, No. 301) 
It is hoped that the present work will assist entomologists to identify the Japanese pipunculid flies at the species level and will stimulate further interests and studies on their habitats, life histories and host relationships as well as their economic importance.

\section{ACKNOWLEDGEMENTS}

We would like to thank Prof. K. Morimoto of Entomological laboratory, Faculty of Agriculture, Kyushu University and Prof. T. A. Uchida, Zoological Laboratory, Faculty of Agriculture, Kyushu University for their kindness in reading the manuscript of this paper.

The first author was fortunate at an early stage of this study to receive kind advice from Prof. K. Yano of Laboratory of Applied Entomology, Faculty of Agriculture, Yamaguchi University, who provided him with information on the Pipunculidae, helped him in accumulating specimens and also kindly read some parts of the manuscript. He is grateful to Assoc. Prof. M. T. Châjô and the staffs of Hikosan Biological Laboratory, Faculty of Agriculture, Kyushu University, for their warm hospitality to his collecting trips to Mt. Hikosan and also for the loan of valuable specimens. He is also grateful to Assist. Prof. Dr. 0. Tadauchi and Dr. K. Ogata of Entomological Laboratory, Faculty of Agriculture, Kyushu University for their generous advice and help in various ways. His special thanks are also due to Dr. T. Goto of Forestry and Forest Products Research Institute, for his valuable suggestion and help; to Mr. K. Konishi of National Institute of Agro-Environmental Sciences and Mr. S. Nomura of Entomological laboratory, Faculty of Agriculture, Kyushu University who kindly accompanied with him to various localities in Japan for collecting trips many times. $\mathrm{He}$ is indebted to Dr. K. Baba (Kitakambara-gun, Niigata Prefecture) for offering him some valuable specimens and kind assistance to his collecting trip to Niigata Prefecture and to Mr. K. Hirano (Iitatemura, Fukushima Prefecture) for his help to his collecting trip to Fukushima Prefecture.

We wish to express our thanks to the following persons for the loan or donation of the specimens in their collections: Prof. S. Takagi and his colleagues (Hokkaido University) ; Prof. T. Okadome and his colleagues (Meijo University) ; Dr. Neal L. Evenhuis and Mr. Gordon T. Nishida (Department of Entomology, Honolulu, Bishop Museum, Hawaii, U. S. A.).

Further thanks are due to the following persons for kind offering of valuable specimens : Dr. Y. Yoshiyasu of Kyoto Prefectural University ; and Miss Ko Myune Kyune, Mr. M. Abe and Mr. Y. Sawada (Entomological Laboratory, Faculty of Agriculture, Kyushu University).

Finally, the first author would like to express his appreciation to the Ministry of Education, Science and Culture of Japan for providing the scholarship and also to the Ministry of Agricultural and Co-operatives, the Thai Government, for supporting his study leave.

\section{MATERIALS AND METHODS}

Most of the specimens examined in this study were mainly obtained by the 
extensive collectings of the first author from various parts of Japan (Fukuoka Prefecture, Oita Prefecture, Yamaguchi Prefecture, Niigata Prefecture, Fukushima Prefecture, Iwate Prefecture, Miyagi Prefecture, Akita Prefecture and Hokkaido) during 1985-1987. Some specimens were borrowed from the collections of Hokkaido University, Meijo University and Bishop Museum (U. S. A). Flies of the family Pipunculidae are generally rare in institution's collections. The reason may be that the random sweeping cannot get many of them. About 1,200 out of 2,000 specimens collected by the first author were caught individually by a sweep net. He used to watch around general low herbacious plants under pine trees or grassy meadow as he walked around, and he could see pipunculid flies hovering slowly up and down. Then he was able to collect them one by one. Occasionally he could get some mating parirs of pipunculid flies. These pairs are exceedingly valuable for the study of sexual dimorphism. And also, the individual catching resulted in yielding the specimens of good condition.

The best method for mounting pipunculid specimens is to use a paper point by attaching the right side of the thorax of the specimen firmly at the tip of the paper point with gum, attempting to hang freely the head, wing and abdomen for the convenience of examination. The mounting must be careful because the head of the flies is easily detached from the body. When the head is detached it is better to mount it on another paper point by attaching its back at the tip of the paper point.

For the examination of male genitalia and other minute characters 10 percent potassium hydroxide was used. After relaxing and clearing the specimens in this liquid, they were placed in a hole slide with glycerine for dissecting or examining under a binocular microscope. To dissect male genitalia very fine and sharp needles were needed. After examination, the specimens were preserved in glycerine in a narrow plastic tube of $0.5 \mathrm{~mm}$ diameter by the method of Andersson (1972).

The body length was measured from the apex of the head to the abdominal terminalia in dorsal position excluding antennae.

\section{MORPHOLOGY AND TERMINOLOGY}

Morphology and terminology of adult pipunculid flies have been well described by Lundbeck (1922) and Hardy (1987). However, to make the keys and descriptions usable for persons not familiar with pipunculid flies the morphology and terminology are also defined and discussed in this paper.

Adult. Head (Fig. 2). The head is mobile, very large in proportion to the body, and is almost entirely occupied by compound eyes. The head is hemispherical in the Chalarinae to nearly spherical in the Nephrocerinae and Pipunculinae. The occiput is very narrow and concealed behind the hind margin of the eyes in the Chalarinae but well-developed as a thickened occiput in the Nephrocerinae and Pipunculinae. The eyes are generally holoptic in the male and dichoptic in the female, but dichoptic in the male of the Chalarinae and the genus Dorylomorpha Aczél. The hind margin of eyes as seen from side are almost straight in the Pipunculinae and Chalarinae but very indented at the middle in the Nephrocerinae. The antenna consists of three segments ; the first segment (scape) is small, generally concealed in the head capsule ; the second segment (pedicel) is moderately large, roughly quadratic, with some usually with bristles above and beneath ; the third segment (flagellum) is the largest, varying in 
shape (reniform, oval, acuminate or rostrate) and size ; the arista are three segmented, with two small basal segments and the long tapering large segment. The mouthparts are of the muscoid type and consist of the clypeus, labrum, maxillary palpi and labellae (proboscis). The maxillary palpi are elongate and enlarged at apex, usually with two sensory setae in the Chalarinae.

The thorax (Fig. 3A and $\mathrm{B}$ ) is generally black in color, opaque or shining, sometimes with brownish or greyish dusting. The particular strong bristles are present on the dorsum of the thorax in the Chalarinae and Nephrocerinae but absent in the Pipunculinae. The propleurae are generally hidden by the occiput, usually with a brush of pubescence (propleural fan) which is absent in Tomosvaryella Aczél, Dorylomorpha Aczél and Eudorylas Aczél. The proepimeron is generally bare but with some pubescence in the Chalarinae. The humeri are variable in coloration from yellow to black, which is good for species grouping.

The legs are mostly simple in shape but variable in coloration which is important to species recognition. The hind trochanters are sometimes transformed in shape or ornamented with some spines. The variations of the hind trochanters have some taxonomic values. The femora are almost bare in Pipunculinae and Nephrocerinae or densely clothed with pubescence in Chalarinae, generally with two rows of serrulated spines beneath in Pipunculinae. The tibiae are generally simple, with or without the posteroapical spur ; the hind tibiae are sometimes bent. The pulvilli and claws are usually enlarged in the female but small in the male.

The wings (Fig. 5) are hyaline to smoky but generally hyaline ; long and narrow, as long as or longer than the body ; the third costal section colored or uncolored. The wing venation varies in different genera. The subcostal vein is long and complete (one species in the genus Cephalops Fallen has an incomplete subcostal vein). The vein R1 is two-branched ; R2 +3 and $\mathrm{R} 4+5$ divergent ; $\mathrm{R} 4+5$ and $\mathrm{Ml}$ are closed together at the apex. The vein M2 is present in the genus Nephrocerus Zetterstedt and in some species of Verrallia Mik and Cephalops Fallen, and it is variable in length but never reaching the wing margin. The veins $\mathrm{CuA} 1$ and $\mathrm{CuA} 2$ are complete. The anal vein is generally complete except for the genus Chalarus Walker almost lacking. The r-m cross vein is short in length, situated in various positions on the discal medial cell. This condition has some taxonomic value. The last section of the vein Ml is straight to very wavy, which makes the cell R5 variable in shape, occasionally uses for species recognition. The calypteres are small and narrow. The halteres consist of the narrow basal stem and the oval or round apical knob ; sometimes they adduce evidence of sexual dimorphism as found in the genus Chalarus Walker (black color in the male but yellow in the female).

The abdomen is variable in shape but generally subcylindrical. The coloration is opaque grey to shining metallic black, rarely yellow except for Nephrocerus Zetter. stedt and some species in the Pipunculinae. Abdominal tergites are almost bare to densely covered with pubescence ; the tergite 1 is generally with a tuft of short or long pubescence anterolaterally. The first to fifth segments in the male and the first to sixth in the female are normal in position but the remainders (abdominal terminalia) are differentiated for copulation and oviposition.

Male : The sixth and seventh tergites are twisted to the right in various degrees: But in the Chalarinae the sixth tergite still appears almost normal in position and the 
seventh tergite is lateral in position. In the Pipunculinae both the sixth and the seventh tergites are ventral in position. The eighth tergite (syntergosternite sensu Hardy 1987) is situated at the apex of the abdomen; greatly varying in shape and size for the Pipunculinae. The structure of the eighth tergite is very important to the recognition of species. In the Chalarinae the eighth tergite is rather small and unchanged in shape, situated at the left side of abdominal terminalia and there is the well-developed ninth sternite (hypandrium) on its right side. The ninth to eleventh tergites in all members of the Pipunculidae are ventral in position. Opposite to them exists the hypandrium (Figs. 4A-B and 13A-B) which is exposed outside at the right side of the abdominal terminalia in the Chalarinae, but in the Nephrocerinae and Pipunculinae it is concealed within the eighth tergite. The hypandrial shape are variable among the subfamilies; e. g. two longitudinal lobes in the Chalarinae, a single roughly rectangular plate in the Nephrocerinae and two lobes in various shape in the Pipunculinae. The ninth tergite (epandrium) is a single plate of varying shape and size. The tenth tergite is composed of two symmetrical or asymmetrical lobes (surstyli), articulated posterolaterally on each side of the epandrium. The surstyli are greatly variable in shape and size. This condition is useful for the recognition of species. The eleventh tergite (cerci) is situated between the epandrium and surstyli, oval in shape, and served as an anus. The third to fifth sternites sometimes are ornamented with short tack-like spines. The sixth to eighth sternites are not discussed in the present work because they are obscure and difficult to distinguish. The aedeagus and its periphallic structures are also not discussed here but the illustration of these structures of all genera and almost all the described species are presented.

Female : The abdominal terminalia are well-developed as an effective ovipositor for inserting eggs into the host body. It is exceedingly variable in shape and size, and this condition is very important to species recognition. It is roughly divided into two parts as the ovipositor base and ovipositor piercer. The ovipositor base is composed of the seventh to ninth tergites, the main area of which is the eighth tergite. The piercer consists of two sclerotized portions, and the genital opening is located between them.

\section{Historical review of the works on the Pipunculidae in Japan}

In Japan, as far as we know, the first described species is Pipunculus kumamotensis Matsumura (1916) which is later treated as a synonym of Eudorylas mutillatus by Yano et al. (1984). The first work on the biology of pipunculid flies was done by Esaki et al. from 1932 till 1941, along with their study on natural enemies of the green rice leafhopper Nephotettix cincticeps (Uhler), a serious pest of rice in Japan. They reported that the percentage parasitism by these flies was as high as 65 percent in 1936. Unfortunately, they neglected to specify the pipunculids which they found. Koizumi (1959) firstly worked on the taxonomy of pipunculid flies as the parasites of the green rice leafhopper N. cincticeps (Uhler). He recognized four species in Japanese fauna : Tomosvaryella oryzaetora Koizumi (Pipunculus sp. in Esaki et al. sensu 1932, 1937), Dorilas (Eudorylas) tsuboii Koizumi (later treated as a synonym of E. javanensis de Meijere), Dorylas (Eudorylas) cruciator (Perkins) (later as a synonym of Eudorylas mutillatus (Loew)), and Dorylas (Eudorylas)orientalis Koizumi. In 1960, he described 
four more species of pipunculids, one of which, Alloneura inazumae Koizumi is the parasite of the zig-zag striped leafhopper Reciliadorsalis (Motschulsky). After the works of Koizumi (1959, 1960), publications on the Pipunculidae are rather meager till Yano et al. (1984) reviewed the Japanese Pipunculidae. They primarily concerned with the flies dwelling in paddy fields and enumerated fourteen species in four genera with some informations on their hosts and distribution.

Recently, Morakote and Yano (1985, 1987, 1988a,1988b) studied the biology of adults and the morphology of immature stages of some pipunculids parasitizing the green rice leafhopper $\mathrm{N}$. cincticeps (Uhler) and provided advanced informations about these flies.

As mentioned above, our knowledge on the Pipunculidae in Japan is rather restricted to the flies inhabiting paddy fields. Only Morakote (1988) gave a knowledge on the Japanese Pipunculidae in general, who described four new species of Nephrocerus collected from the original vegetation.

\section{CLASSIFICATION}

There are many arguments in the arrangement of genera of the family Pipun. culidae according to the discrimination of the following characters : the wing vein M2, the propleural fan and the arrangement of setae on the dorsum of the thorax. Enderlein (1936) regarded the wing vein M2 as having at least generic value and erected two new genera : Jassidophaga from genus Verrallia Mik because of the absence of the wing vein M2, and genus Cephalosphaera from Pipunculus Latreille because of the presence of the wing vein M2. His work was followed by Aczél (1939a, 1939b, 1940) and Hardy (1943). Collin (1945) disagreed with the above authors and discussed the wing vein M2 has some variations and should not have the generic value. His idea was followed by Coe (1966b). We agree with Collin (1945) and Coe (1966) by the reason that there is a certain variation of the wing vein M2.

For the genus Cephalops Fallén which Hardy (1943, 1975, 1987) placed as a subgenus of Pipunculus Latreille, Collin (1956) recognized as a distinct genus for the reason that the differentiation of setae on the dorsum of the thorax is a distinct character for generic value. We accept the opinion of Collin (1956).

We followed Aczél(1939a), Coe (1966b), Meyer and Bruyn (1985) and Kozanék (1987) on the concept that the propleural fan is distinct and is served for at least the generic character, placing Eudorylas as a genus distinct from genus Pipunculus Latreille because of the lacking of the propleural fan, although Hardy $(1943,1987)$ placed Eudorylas Aczél as a subgenus of Pipunculus Latreille.

The genus Tomosvaryella Aczél is a difficult genus and Collin (1945) said that it is a synonym of Alloneura Rondani. We use Tomosvaryella Aczél in the present work because Alloneura Rondani has been suppressed by I. C. Z. N. (Opinion 597, 1961), but some authors (Coe, 1966b ; Meyer and Bruyn, 1985) have still used Alloneura in their papers. 


\section{Systematic treatment}

\section{Key to subfamilies, tribes and genera of the Japanese Pipunculidae}

1. Ocellar triangle with a pair of bristles and some fine pubescence ; head hemispherical ; occiput very narrow and concealed behind hind margin

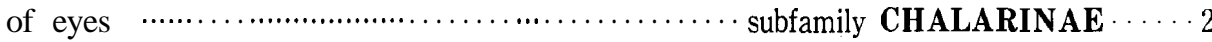
Ocellar triangle bare ; head nearly spherical ; occiput swollen and clearly seen

2. Wing venation complete, discal cell closed

- genus Verrallia Mik (total 8 species ; 3 n. spp. and 4 new record to Japan) Wing venation incomplete ; third and fourth sections of vein Ml, vein dm-cu and anal vein disappeared

........... genus Chalarus Walker (new record to Japan ; total 10 spp., 7 n. spp.)

3. Dorsum of thorax with strong bristles in particular areas ; hind margin of eyes indented at middle

-.. subfamily NEPHROCERINAE --*a-- genus Nephrocerus Zetterstedt (total 4 spp.)

- Dorsum of thorax without strong bristles ; hind margin of eyes almost straight subfamily PIPUNCULINAE

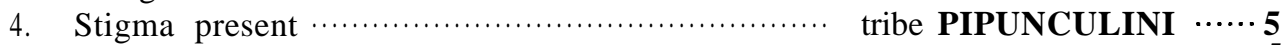
Stigma absent $\ldots \ldots \ldots \ldots \ldots \ldots \ldots \ldots \ldots \ldots \ldots$.

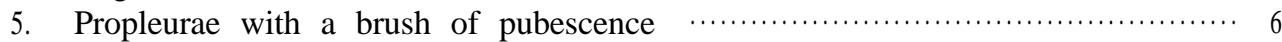

- Propleurae bare ... genus Eudorylas Aczél (total 41 spp.; 32 n. spp. and 3 spp. new record to Japan)

6. Dorsum of thorax almost bare but with a differentiated seta on each dorsocentral line

…. genus Cephalops Fallén (total 14 spp. ; 9 n. spp and 3 spp. new to Japan)

- Dorsum of thorax entirely covered with short fine hairs ; setae not differentiated on dorsocentral line

..... genus Pipunculus Latreille (total 12 spp. ; 7 n. spp. ; 4 spp. new to Japan)

7. Cross vein $\mathrm{r}-\mathrm{m}$ of wing situated near basal portion of discal medial cell ;

eyes of male dichoptic

*. genus Dorylomorpha Aczél (total 12 spp.; 6 n. spp and 5 spp. new record to Japan)

- Cross vein r-m of wing situated near middle of discal medial cell-;

eyes of male holoptic

genus Tomosvaryella Aczél (Total 8 spp. ; 1 sp. new to Japan)

\section{Family Pipunculidae}

Family Pipunculidae belong to the superfamily Syrphoidea, section Aschiza, suborder Cyclorrhapha, order Diptera, and stand between family Platypezidae and 
Syrphidae in phylogenic position. The members of this family are easily recognized by their enormous eyes which almost entirely occupy the head, and are commonly called big-eyed flies. Adult flies are rather small in size with body length ranging from 2-12 $\mathrm{mm}$ but generally about $4-5 \mathrm{~mm}$. Their body coloration is usually black to greyish black, rarely with yellow color except members of the subfamily Nephrocerinae and some species of subfamily Pipunculinae. They are generally hovering on or in low vegetations and easily observed in a shining and calm day. Larvae of pipunculid flies are endoparasites of various homopterous insects, particularly in families Cicadellidae, Delphacidae and Cercopidae. Pipunculid flies are believed to play some important role as biological control agents of some homoptereous insect pests of economic crops such as rice and sugarcane.

\section{Subfamily CHALARINAE}

The members of the subfamily Chalarinae are characterized by having the hemispherical head, the very narrow occiput and the protruded ocellar triangle which clothed with some pubescence and a pair of long bristles. Up to now only two genera are found in this subfamily.

\section{Genus VERRALLIA Mik}

Verrallia Mik, 1899, Wien. ent. Ztg., 18 : 269. Type species : Cephalops aucta Fallen, 1817, Syrphici Sveciae : 61, by original designation.

Prothechus Rondani, 1856, Dipt. Ital. Prodromus, 1 : 139, suppressed by I. C. Z. N. (1961 : 230).

Jassidophaga Aczél, 1939 : 20. Type species : Pipunculus pilosus Zetterstedt (orig. desi.). Enderlein's earlier proposal (1936:129) invalid under Art. 25 c of the Rules.

The flies of the genus are characterized by having a pair of bristles and some pubescence on the ocellar triangle, the very narrow and concealed occiput, and the dorsum of the thorax with strong bristles in particular areas. They are separated from genus Charalus Walker by having the complete wing venation. The type species of the genus has the wing vein M2. Enderlein (1936) separated a group of species which do not have the wing vein M2 and erected a new genus Jassidophaga for them. Aczél (1939a) and Hardy (1943) followed Enderlein (1936), but Collin (1945) and Coe (1966b) disagreed by the reason that the wing vein M2 has no generic value. We accept the opinion of Collin (1945) and Coe (1966).

To date only one species ( $V$.beatricis Coe) has been recorded in Japan by Yano et al. (1984). In this paper we record seven more species including three new species. The Japanese flies belonging to this genus are moderately large size with the body length ranging from 3.8 to $7.3 \mathrm{~mm}$. They seem to be abundant in Japan because we collected many of them in various localities. They were usually found hovering among low herbacious plants and only occasionally seen in grass land. At one time the first author caught a few flies by a light trap.

Concerning the hosts of this genus there have been some reports (Coe, 1966b; Whittaker, 1969 ; Waloff, 1975, 1980 ; Linnane and Osgood, 1977) which reveal that 
they parasitize the hompterous insects of the families Cercopidae and Cicadellidae.

Key to known males of Japanese VERRALLIA

1. Wing vein $\mathrm{M} 2$ present on the last section of wing vein $\mathrm{Ml}$, all body pubescence black ; scutellum with two pairs of strong marginal bristles and two pairs of long fine marginal pubescence ; sternite 5 with a row of four short tack-like spines on each side of posterior margin ; genitalia as shown in Fig. 6E

V. rebunensis Morakote, sp. $n$.

- Wing vein M2 absent

2. All femora without a wart beneath; scutellum with 6-8 marginal bristles ; genitalia (Fig. 16A-C); paramere serrated with nine long

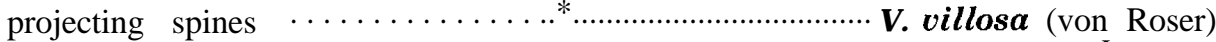

- At least fore and mid femora with a wart beneath $\ldots \ldots \ldots \ldots \ldots \ldots \ldots \ldots \ldots \ldots \ldots \ldots . . . \ldots \ldots \ldots$

3. Third antennal segment yellowish ; all body pubescence and bristles almost pale yellow ; rather large species (about $5.6 \mathrm{~mm}$ ) ; scutellum with 10-12 marginal bristles; genitalia (Fig. 13A and B) ; paramere serrated with 6-7 long projecting spines …............ V. pala Morakote, sp. n.

- Third antennal segment black or brownish black, almost all body pubescence black

4. Very deep black and densely pilose species; scutellum with 8-10 black marginal bristles ; fifth sternite with a group of many short tack-like black spines on each side near posterior margin (Fig. 15C) ; genitalia (Fig. 15A, B and D) ; paramere with a moderately long spine subapically (longer than that of $V$.pilosa)

V. setosa (Verrall)

Brownish black and not much densely pilose species ; scutellum with 4 -8 long marginal bristles ; abdomen black ; fifth sternite with a row of 2-4 short tack-like spines on each side near posterior margin

5. Last section of fourth vein (Ml) of wing without any sign of kink, almost straight ; wing rather clear ; small species (about 3.8-4 mm); scutellum with 4 distinct long marginal bristles ; genitalia (Fig. 14D and E) ; paramere with rather long projecting spine subapically (longer than that of V.setosa)

V. beatricis Coe

- Last section of fourth vein (Ml) of wing with a sign of kink, very undulating ; wing not so clear

6. Third antenna1 segment almost entirely brownish black; scutellum with 4-8 long black marginal bristles ; genitalia (Fig. 14A-C); paramere with very short projecting spine subapically (shorter than that of V. setosa) .............. V. pilosa (Zetterstedt)

- Third antennal segment tinged with brownish yellow on anterior half ; scutellum with 4 distinct black marginal bristles ; genitalia (Fig. 16D and $\mathrm{F}$ ) ; paramere without any projecting spine ; aedeagus with a bifid plate-like process at middle of posterior portion 
Key to known females of Japanese VERRALLIA

1. Wing vein $\mathrm{M} 2$ present on last section of wing vein $\mathrm{Ml}$; large species (body length about $7 \mathrm{~mm}$ ) ; wing shorter than body ; legs almost entirely yellow except coxae; ovipositor very large, forming a very long piercer (Fig. 5)

V. spectabilis Collin

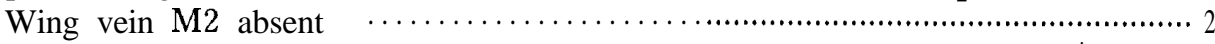

2. Pulvilli large, at least twice as long as last tarsal segment $\ldots \ldots \ldots \ldots *^{*} \ldots \ldots \ldots \ldots . . . .3$

- Pulvilli small, equal or slightly longer than last tarsal segment $\ldots \ldots \ldots \ldots \ldots \ldots \ldots+4$

3. Third antennal segment yellowish ; second antennal segment with pale ; bristles above and beneath ; body pubescence and bristles almost pale, scutellum with 6-8 long marginal bristles ; ovipositor as shown in Fig. 17B …..................................................

- Third antennal segment blackish ; second antennal segment with some black bristles above and pale beneath ; scutellum with 6-8 long marginal bristles ; ovipositor (Fig. 17A) ….................. V. villosa (von Roser)

4. Scutellum with 8-10 long black marginal bristles ; tibiae and tarsi blackish ; pulvilli equal or slightly shorter than last tarsal segment ; ovipositor (Fig. 18B) with globular base and forming a moderately long piercer (longer than that of $V$. beatricis but shorter than in $V$.pilosa)

V. setosa (Verrall)

Scutellum with 4-6 long marginal bristles ….................................. 5

5. Third antennal segment brownish yellow on anterior half; tibiae and tarsi yellowish brown; pulvilli slightly longer than last tarsal segment ; ovipositor (Fig. 17C) moderately long, forming a thick piercer

Third antenna1 segment entirely black

V. japonica Morakote, sp. n.

6. Tibiae and tarsi obscurely brownish black ; pulvilli slightly longer than last tarsal segment ; small species ; ovipositor (Fig. 18C) with small oval base, forming a rather short upcurved piercer …........... V. beatricis Coe

- Tibiae and tarsi brownish yellow; pulvilli slightly longer than last tarsal segment ; ovipositor (Fig. 18A) with globular base, forming a very long upcurved piercer (longer than that of $V$. setosa)

V. pilosa (Zetterstedt)

\section{Verrallia spectabilis Collin}

Verrallia spectabilis Collin, 11941, Proc. r. ent. Soc., Lond., (B) 10 (11) :: 218.

Female (Fig. 5).

Head hemispherical, hind margin of eyes almost straight, occiput concealed, with a circular row of short black pubescence, eyes widely separated ; frons parallel-sided from level of medial ocellus to lower one-third then gradually widening to widest point at base of antennae, cinereous except lower third silvery pubescent ; antennae with first and second segments black, the latter with many long black bristles above and long pale bristles beneath ; third antennal segment yellow, obtuse below, about twice 
as deep as the second ; arista with yellow enlarged base, the remainder tapering black, longer than third segment.

Thorax and scutellum entirely cinereous, sparsely covered with short black hairs on dorsum, thorax with very strong black bristles on particular areas as follows : Three on notopleuron, each on supra-alar and end of dorsocentral line, and three on postalar callus; scutellum with three pairs of long black marginal bristles ; pleurae greyish, each propleura and anepimeron with a tuft of moderately long pale fine pubescence near anterior margin.

Legs mainly yellow except coxae and trochanters greyish, femora rather stout ; front femora with a row of about 12 short black bristles posterodorsally ; mid femora with a row of dense fine pale pubescence posteromedially ; hind femora with a row of about 8-10 moderately long black bristles anterodorsally ; hind tibiae without any long hairs ; pulvilli, about 1.5 times as long as last tarsal segment, claw rather short about half as long as pulvillus.

Wings hyaline, shorter than body ; third costal section tinged with brown, slightly shorter than the fourth ; r-m situated about middle of discal medial cell ; vein M2 present at about basal one-sixth of last section of fourth vein (Ml) ; base of calypteres with densely yellow hairs, halteres brownish.

Abdomen considerably long in proportion to the body, about 2.5 times as long as its thorax, greyish, tergites 2-6 sparsely covered with short black hairs, tergite 1 with a tuft of intermixed pale and black of moderately long pubescence anterolaterally, pale bristles is on anterior half; all sternites with numerous minute tack-like spines beneath ; ovipositor with well-developed piercer ; piercer very large and long, slightly upcurved apically, apex extending back to posterior margin of sternite 3 ; base of ovipositor very small and short compared with piercer.

Length : Body $7.3 \mathrm{~mm}$; wing $6 \mathrm{~mm}$.

Specimens examined: 1우, Iitatemura, Mt. Abukuma, Fukushima Pref., Honshu, 7. vii. 1985 (R. Morakote) ; 1 우, same data, 18. vii. 1985 ; 1 우, Mt. Adatara, Fukushima Pref., Honshu, 29. vii. 1971 (M. Suwa) ;1우, Sapporo, 28. vii. 1915 (T. Okuni).

Host : Unknown.

Distribution : Japan (Hokkaido, Honshu), U. S. S. R. (Tigrovaja, Sutshan District).

Remarks: This is the first record of this species from Japan. It is the largest species in the genus and easily distinguished from other species by having the yellow legs, the short wings and the very large and long piercer.

Verrallia rebunensis Morakote, sp. $\mathrm{n}$.

Male.

Body pubescence and bristles mostly deep black. Head hemispherical ; hind margin of eyes almost straight; eyes narrowly separated ; frons cinereous except lower one-fourth with silvery pubescence, gradually narrowing from ocellar triangle to narrowest point at middle (almost touching), then widening again to widest point at base of antennae which is about twice as wide as frons at level of medial ocellus ; antennae (Fig. 6F) all black ; second segment with many long black bristles above and beneath, those beneath are longer ; arista long, entirely black. 
Thorax (Fig. 6A) velvety black, densely covered with moderately long pubescence on dorsum, with long black bristles on particular areas as follows : Three on notopleuron, one on supra-alar and end of dorsocentral line, and two on postalar callus. Scutellum velvety black, with four long black bristles and four fine hairs on posterior margin. Pleurae greyish ; notopleurae more greyish ; propleurae with a fan of pubescence ; anepimeron with a group of fine black pubescence near anterior margin.

Legs all black, except the joints between femora and tibiae brownish ; all femora without any wart beneath fore and mid femora with regular and irregular rows of many pubescence posteriorly; hind femora with a diagonal row of about 7-10 long black bristles anteromedially; pulvillus yellow, rather small, about as large as last tarsal segment.

Wings hyaline ; stigma dark brown, extending back to tip of Sc; third costal section slightly longer than fourth, $\mathrm{r}-\mathrm{m}$ situated about middle of discal medial cell, vein M2 present at basal one-fifth of last section of vein Ml, slightly shorter than posterior marginal cross vein, base of calypteres with densely yellow hairs, halteres dark brown.

Abdomen rather flat; tergites 1-5 densely covered with moderately long black pubescence ; tergite 1 with a tuft of intermixed yellow and black pubescence anterolaterally ; abdominal sternite 5 (Fig. 6B) with a row of four tack-like spines on each side near posterior margin.

Genitalia as shown in Fig. 6E ; hypandrium well developed, separated longitudinally into two long arched lobes; epandrium small, much wider than long; each surstylus with round posterior margin as seen from side; parameres attached at base of aedeagus, very long, thread-like shape.

Wing length : $4.6 \mathrm{~mm}$.

Holotype: $0^{7}$ Rebun, Hokkaido, 1. viii. 1958 (S. Takagi), in the collection of Hokkaido University.

Host : Unknown.

Distribution : Japan (Hokkaido : Rebun).

Remarks: This species closely resembles V.aucta Fallen but differs from the latter as follows : the tarsi black (yellow to brown in aucta), the femoral bristles well-developed ; and the parameres is decidedly different from that of aucta as illustrated by Coe (1966b).

\section{Verrallia pilosa (Zetterstedt)}

Pipunculus pilosus Zetterstedt, 1838, Insecta Lapp. : 579.

Verrallia pilosa : Mik, 1899, Wien. ent. Ztg., $18: 137 .-$ Verrall, 1901, Brit. Files, 8 : 71. - Cresson, 1911, Trans. Amer. ent. Soc., $36: 275$. Lundbeck, 1922, Diptera Danica, $6: 66 . \quad$ Collin, 1931, Ent. mon. Mag., $67: 235 ;-1956$, Opus. ent., $21: 155 . \longrightarrow$ Coe, 1966, Proc.r. ent. Soc. Lond., (B) $35: 158 ;-1966$, Handbk. Ident. Brit. Ins., 10 (2C) : 34. —— Lauterer, 1981, Acta Mus. morav. (Sci. nat.), 66:127. -Meyer and Bruyn, 1985, Doc. Trv. Inst. r. sci. Nat. Belg., 24 : 8.

Jassidophaga pilosa : Enderlein, 1936, Dipt. Tierwelt. Mittleur., $4: 129$. - Aczél, 1939, 2001. Anz., $125: 20 ;-1948$, Acta 2001. Lilloana, $6: 40$. — Hardy, 1943, Univ. Kans. Sci. Bull., 29 (1) : 31. 
Pipunculus fasciata von Roser, 1840, Corres Bl. wurtt. landw. Ver. Stuttg. (N. S.), 17 (1) : 55.

P. modesta Schiner, 1862, Fauna Austriaca, Dipt., $1: 246$.

P. ruralis Walker, 1834, Ent. Mag., $2: 268$.

\section{M ale.}

All body pubescence and bristles black. Eyes almost touching at middle of frons (about half as long as frontal triangle) ; ocellar triangle blackish ; frontal triangle and face silvery pubescent; antennae brownish black; second antennal segment with black bristles above and longer ones beneath, third antennal segment oval, about 1.5 times as deep as second ; arista black, about twice as long as third antennal segment.

Thorax and scutellum velvety black, with obscurely brownish dust on dorsum ; scutellum with 4-8 long marginal bristles; notopleuron and pleurae cinereous ; propleural fan and pteropleural pubescence black.

Legs almost entirely black, except a joint between femora and tibiae ; fore and mid femora with a wart beneath on about basal two-thirds ; hind tibiae with a row of 8-10 pubescence anterolongitudinally ; pulvilli yellow, about as long as last tarsal segment.

Wings hyaline, slightly tinged with brown ; stigma dark brown, almost extending back to tip of Sc; third costal section about twice as long as fourth ; r-m near middle of discal medial cell ; last section of fourth vein (Ml) with a sign of kink about basal one-fourth to one-fifth, very undulating ; halteres brownish yellow ; base of calypteres with numerous brownish black hairs.

Abdomen (Fig. 11B) about 1.5 times as long as thorax, black, with obscurely brownish dust ; posterolateral corner of tergites 2-4 greyish, clearly seen from side ; abdominal pubescence all black, short on dorsum, longer at side, especially tergite 1 with a tuft of long pubescence anterolaterally; sternite 5 with a row of 3-4 short tack-like black spines on each side near posterior margin ; tergites 7 and 8 black, brownish pruinose.

Genitalia (Fig. 14A-C) moderately large ; hypandrium black, brownish pruinose ; epandrium black, rather broader than long; surstyli rather short and blunt, distally clothed with some short hairs; parameres raised on either side of aedeagus, rather shorter than aedeagus, with a very short projecting spine subapically, attached with membranous sheath posterodistally.

Length : Body 4-4.5 mm ; wing 4-4.5 mm.

\section{Female.}

Mostly resembling the male but differing from as follows: Body pubescence shorter and sparser than in male ; body coloration paler, with brownish dust. Eyes separated narrowly from vertex to base of antennae, front ommatidial facets enlarged ; frons greyish, with a row of short pale hairs running down along each side margin. Thorax and scutellum greyish, brownish pruinose on dorsum ; notopleuron and pleurae cinereous ; scutellum with 4-6 long marginal bristles.

Legs dull greyish black ; tip of femora brownish ; tibiae and tarsi brownish yellow ; pulvilli yellow, slightly longer than last tarsal segment ; femoral pubescence rather weaker than in male ; all femora with a trace of wart beneath near middle. 
Wings similar to that of male but halteres and base of calypteres with numerous yellow hairs.

Abdomen greyish, with brownish dust ; tergites 2-4 much darker on anterior two-thirds when viewed from above ; abdominal pubescence mostly black, except a tuft of long pubescence on anterolateral corner of tergite 1 and some pubescence on anterior of tergite 2 pale ; tergite 2 longest. Ovipositor (Fig. 18A) moderately large ; base globular shape, black, with greyish dust ; piercer rather long, moderately upcurved, dark brown in color.

Length : Body $4.2 \mathrm{~mm}$; wing $4.4 \mathrm{~mm}$.

Specimens examined. (Hokkaido) $1 \sigma^{7}$, Sounkyo, Mts. Daisetsu, Kamikawa, 26. vi. $1986 ; 1 \sigma^{7}$, same locality, 11. vi. $1986 ; 2$ ๙ $^{\nearrow}$, Nukabira, Kamishihoro, Tokachi, 28. vi.

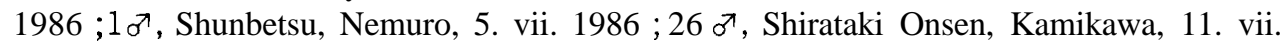
1986 ;1우, Ashoro, Tokachi, 2. vii. 1986 ; all were collected by R. Morakote. 1우, Sapporo, Ishikari, 7. vii. 1966 (M. Suwa) ; 2 우우, same locality, 8. vii. 1959 (T. Kumata); 1 우, Mts. Daisetsu-zan, Kamikawa, 13. vii. 1960 (K. Kamijo) ;1우, Rishiri, 4. viii. 1958 (K. Kamijo).

H ost : Unknown.

Distribution : Japan (Hokkaidd), Europe, North America.

Remarks : This is the first record of this species from Japan. The Japanese specimens were identified as $V$. pilosa by using the genital characters because other characters seem to be variable. The genitalia of this species were firstly illustrated by Coe (1966), and later by Lauterer (1981). The male specimens of $V$. pilosa found in Japan differ from the description by Verrall (1901), Cresson (1911), Lundbeck (1922), Collin (1931), Hardy (1943) and Coe (1966a) as follows : Scutellum with 4-8 long marginal bristles (while the above authors described that scutellum with 4-6 long marginal bristles) ; all body pubescence black ; hairs below second antennal segment, pubescence behind mid femora and a tuft of long hairs on anterolateral corners of tergite 1 occasionally pale.

The female Japanese specimens were identified as $V$. pilosa based on the characters of the ovipositor, although there is a slight difference in the description between by Coe (1966a) and this paper. The female Japanese specimens have the tibiae and tarsi brownish yellow at the base and tip ; and the tarsi are usually entirely darkened.

\section{Verrallia villosa (von Roser)}

Pipunculus villosa von Roser, 1840, Corres Bl. wurtt. landw. Ver. Stuttg. (N. S.), $17: 55$. Cephalops villosa: Verrall, 1894, Ent. mon. Mag., 2 (30) : 141.

Prothechus villosa: Becker, 1897, Berlin. ent. Zschr., 42 : 95.

Verrallia villosa: Mik, 1899, Wien. ent. Ztg., 43 : 137. — Verrall, 1901, Brit. Flies, 8 : 74. Collin, 1931, Ent. mon. Mag., $67: 235$. - Aczél, 1948, Acta zool. Lilloana, $6: 43$. Coe, 1966, Handbk. Ident. Brit. Ins., 10 (2C) : 32. Lauterer, 1981, Acta Mus. morav. (Sci. nat.), $66: 131$. - Meyer and Bruyn, 1985, Doc. Trav. inst. r. sci. Nat Belg., 24 : 9.

Male.

Differing from the male of $V$. pilosa as follows: All femora without any wart 
beneath ; scutellum with 6-8 long black marginal bristles ; tergites 2-5 with more conspicuous grey dust at posterolateral corners ; genitalia (Fig. 16A-C): surstyli somewhat longer than those of pilosa; parameres slightly shorter than aedeagus, serrated with nine projecting spines from middle to subapical tip.

Length : Body 4.5-5 mm ; wing 4.5-5 mm.

\section{Female.}

Differing from female of $V$.pilosa as follows : Scutellum with 6-8 long black marginal bristles ; pulvilli very large, about twice as long as last tarsal segment ; ovipositor (Fig. 17A) with oval base ; piercer moderately long and thick, slightly upcurved.

Length : Body $4.2 \mathrm{~mm}$; wing $4.2 \mathrm{~mm}$.

Specimens examined. (Hokkaido) $6 \sigma^{7} \sigma^{7} 71$ 우우, Nukabira, Kamishihoro, Tokachi, 27-29. vi. 1986 ; 2워 18 우우, Akankohan, Mt. 0-akan, Kushiro, 3-4. vii. 1986 ;13우우, Ashoro, Tokachi, 30. vi. 1986 ;9 우우, same locality, 2. vi. 1986 ; 11 우우, Kamishibetsu, Kushiro, 5. vii. 1986 ;4우우, Sounkyo, Mts. Daisetsu, Kamikawa, 26. vi. 1986 ;2 우우, same locality, 11. vii. 1986 ;3우우, Raus onsen, Nemuro, 8. vii. 1986, 1 우, Iwabetsu, Utoro, Abashiri, 7. vii. 1986 ; all were collected by R. Morakote. 2 우우, Ashoro, Tokachi, 18-21. vi. 1985 (M. Abe) ; 16, Maruyama, Sapporo, 22. vi. 1958 (S. Momoi) ; $1 \sigma^{7}$, Sapporo, 26. v. 1960 (K. Kamijo) ;1 $\sigma^{7}$, Aizankei, '16. vii. 1960 (S. Takagi) ; 16,

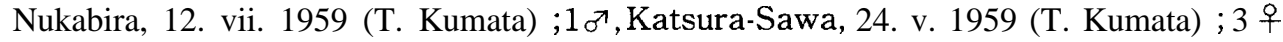
우, Apoi, 23. vi. 1959 (T. Kumata). (Honshu) 16, Kurohime Yama, Nagano, 8. vi. 1959 (K. Kamijo).

Host : Unknown.

Distribution: Japan (Hokkaido, Honshu), Europe.

Remarks : This is the first record of this species from Japan. The male of this species is distinguished from other species by having no trace of a wart on the underside of the femora. It is noted here that the combination in sexes in this species is uncertain. The female specimens examined were identified as V. villosa according to the description of Coe (1966a). This species is the most abundant in Japan.

\section{Verrallia setosa Verrall}

Verrallia pilosa var. setosa Verrall, 1901, Brit. Flies, $8: 73$.

Verrallia setosa : Collin, 1931, Ent. mon. Mag., 67 : 235. —- Coe, 1966, Handbk. Ident. Brit. Ins., 10 (2C) :32. L Lauterer, 1981, Acta Mus. morav. (Sci. nat.), $66: 130$. — Meyer and Bruyn, 1985, Doc. Trav. Inst. r. sci. Nat. Belg., 24 : 8.

$M$ ale.

Rather similar to the male of V. villosa than the male of V.pilosa and differing from both of them as follows : Very deep black and densely pilose species ; scutellum with 8-10 long black marginal bristles ; abdomen rather long and narrow ; sternite 5 with a group of many short tack-like black spines on each side near posterior margin ; genitalia as shown in Fig. 15A, B and D; each paramere with a projecting spine subapically as in pilosa but longer, with membranous sheath postero-distally which has many obscurely minute spines. 
Length : Body 5-5.5 mm ; wing 5-5.5 mm.

\section{Female.}

Differing from the female of V.pilosa as follows : Scutellum with 8-10 long black bristles ; tibiae and tarsi blackish ; pulvilli very small, shorter than or equal to last tarsal segment ; ovipositor quite similar to that of pilosa but shorter.

Length : Body $4 \mathrm{~mm}$; wing $4.2 \mathrm{~mm}$.

Specimens examined. (Hokkaido) 46 万', Mitsumai, Sapporo, Ishikari, 24. vii. 1986 ;

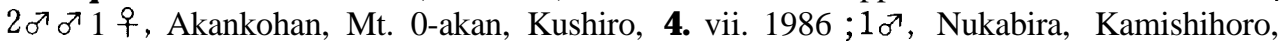
Tokachi. 28. vi. 1986 ; all were collected by R. Morakote. $1 \sigma^{7}$, Sounkyo, 6. viii. 1960 (S. Ueda) ; $1 \sigma^{7}$, Rishiri, 14. vii. 1968 (H. Takizawa) ;1 $1 \sigma^{7}$, Maruseppu, Kitami, 5. vii. 1974 (T. Kumata et al.) ; 1 우, Daisetsu-zan, 12. vii. 1960 (K. Kamijo). (Honshu) 1ðð, Kawaranobo, Mt. Hayachine, Iwate Pref., 15. vii. 1985 (light trap) (R. Morakote).

Host : Unknown from Japan ; in England, Microposis flavicollis (Linnaeus), (Hemiptera : Cicadellidae) by Waloff (1980).

Distribution : Japan (Hokkaido, Honshu), Europe.

Remarks : This is the first record of this species from Japan. The male of $V$. setosa is distinguished from other congeneric species by the very deep black coloration of the body and hairs and by the fifth sternite bearing with a group of many short tack-like black spines on each side near the posterior margin. The female differs from other species by having the tibiae and tarsi blackish, and the pulvillus very small, shorter than or equal to the last tarsal segment.

\section{Verrallia beatricis Coe}

Verrallia beatricis Coe, 1966, Proc. r. ent. Soc., Lond., (B) $35: 159$; - 1966, Handbk. Ident. Brit. Ins., 10 (2C) : 32. — Lauterer, 1981, Acta Mus. morav. (Sci. nat), 66 : 126. - Yano et al., 1984, Trans. Shikoku ent. Soc., $16: 56$.

\section{M ale.}

Closely resembling the male of $V$. pilosa but differs as follows : Smaller ; scutellum with 4 strong black bristles ; wings rather clear, last section of fourth vein almost straight, without any sign of kink ; genitalia as shown in Fig. 14D and E ; paramere with a very long projecting spine subapically (longer than that of V. setosa and pilosa), without any membranous sheath posteriorly.

Length : Body 3.8-4 mm; wing 4-4.2 mm.

\section{Female.}

Differing from the female of V. pilosa as follows : Scutellum with four distinct black marginal bristles ; tibiae and tarsi dark brown; pullvilli about as long as last tarsal segment ; ovipositor (Fig. 18C) with oval base ; piercer rather short (shorter than that of V. setosa).

Specimens examined. (Hokkaido) $7 \sigma^{7} \sigma^{7} 9$ 우우, Akankohan, Mt. 0-akan, Kushiro, 4. vii. $1986 ; 3 \sigma^{7} \sigma^{\nearrow}$, Nukabira, Kamishihoro, 28. vii. $1986 ; 2 \sigma^{7} \sigma^{7}$, Sounkyo, Mts. Daisetsu, Kamikawa, 8. vii. 1986 ; 1 우, Iwabetsu, Utoro, Abashiri, 7. vii. 1986 ; all above were 
collected by R. Morakote ;1 $\sigma^{7}$, Ashoro, Tokachi, 11. vii. 1985 (M. Abe).

Host : Unknown.

Distribution: Japan (Hokkaido, Honshu), Europe.

Remarks: The male of this species is easily distinguished from other species of the genus by having the clear wing, and the last section of the fourth vein (Ml) almost straight. The female specimens examined here are different from the description of Coe (1966a) by having the tibiae and tarsi dark brown, and the pulvilli about as long as the last tarsal segment.

Verrallia pala Morakote, sp. n.

Male (Fig. 8).

Ocellar triangle black, protruded, with some pale pubescence and a pair of long pointing forwardly pale bristles ; eyes almost touching on frons for a distance about as long as frontal triangle, frontal triangle and face silvery pubescence ; first and second antennal segments dull black; second segment with pale bristles above and longer ones beneath ; third antennal segment oval, bright yellow, large, about twice as deep as second segment.

Thorax and scutellum light velvety black on dorsum, covered with exceedingly dense and erect long pale hairs ; bristles of thorax pale ; scutellurn with 10-12 long pale marginal bristles ; notopleuron and pleurae light greyish ; propleural pubescence pale ; anepimeron with a tuft of pale fine hairs.

Legs with coxae, trochanters and femora dull black, greyish pruinose ; tibiae and tarsi brownish yellow ; pulvilli bright yellow, about as long as last tarsal segment ; four anterior femora with a large wart beneath at about basal two-thirds, with irregular rows of numerous long pale pubescence posteriorly ; hind femora with a diagonal row of strong pale bristles anteriorly; hind tibiae with a regular row of numerous pale pubescence.

Wings hyaline, slightly tinged with brown ; stigma dark brown, extending back to tip of Sc, about twice as long as fourth costal section; last section of fourth vein (Ml) very undulating, with a sign of kink at basal one-fifth; halteres yellow ; base of calypteres with numerous yellow hairs.

Abdomen (Figs. 7 and 12), quite large and long, light velvety black on dorsum, greyish to brownish at sides ; abdominal pubescence short and black dorsally, long and pale laterally ; tergite 1 with a tuft of long pale pubescence anterolaterally ; tergite 2 longest ; tergite 6 shortest ; tergites 7 and 8 turned to the right, but still clearly seen from above ; sternite 5 with a row of 3-4 short tack-like spines on each side near posterior margin.

Genitalia (Fig. 13A and B) large ; hypandrium black with brownish to greyish dust, large and long, about as long as tergites 7 and 8 combined, placed at the right side of abdominal terminalia, separated or splitted dorso-medially into two longitudinal lobes ; epandrium brownish black ; surstyli brownish black, covered with numerous short hairs distally; paramere slightly shorter than aedeagus, each serrated with 6-7 long projecting spines from middle to subapical tip.

Length : Body 5-5.5 mm ; wing 5.2-5.7 mm. 
F emale (Fig. 9).

Eyes separated from ocellar triangle to base of antennae, almost parallel-sided, as wide as ocellar triangle, with a row of short pale hairs running down on each side of frons from vertex to lower one-third of frons, front ommatidial facets enlarged.

Thorax and scutellum opaque grey on dorsurn, more cinerous on notopleuron and pleurae ; thoracic pubescence shorter and sparser than in male ; scutellum with 6-8 long pale marginal bristles.

Leg and wing mostly similar to those of male but third costal section of wings longer than fourth costal section in female.

Abdomen brownish grey, about 1.5 times as long as thorax, tergite 1 shortest ; tergite 2 longest ; abdominal pubescence short and black on dorsum, long and pale at side, sparser than in male ; tergite 1 with a tuft of long pale pubescence anterolaterally.

Ovipositor (Fig. 17B), large and stout ; base oval, brownish grey ; piercer about 1.7 times as long as base, moderately upcurved, brownish yellow apically, brownish black basally.

Length : Body $5 \mathrm{~mm}$; wing $5.3 \mathrm{~mm}$.

Holotype: $\sigma^{7}$ (Type No. 2721, Kyushu Univ.), Hitsujigaoka, Sapporo, Ishikari, Hokkaido, 23. vi. 1986 (R. Morakote).

Paratypes: (Hokkaido) 161 우, same data as holotype ; $26 \sigma^{71} 1$ 우, Sapporo, Ishi-

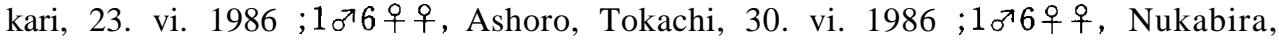
Kamishihoro, Tokachi, 28-29. vi. 1986 ; 4 우우, Kamishibetsu, Kushiro, 5. vii. 1986 ;6우 우, Saroma, Abashiri, 10. vii. 1986 ;1우, Shirataki Onsen, Kamikawa, 11. vii. 1986 ; all were collected by R. Morakote ;1 $\sigma^{7}$, Sapporo, 6. vi. 1968 (Torikura) ;1 $\sigma^{7}$, Sapporo, 20. vi. 1969 (M. Suwa). (Honshu) 2 우우, Kurohime Yama, Nagano, 8. vi. 1959 (K. Kamijo). (Kyushu) 1 우, Mt. Hikosan, Fukuoka Pref., 2. vi. 1972 (Collection of Hikosan Biological Lab.) ; 4 우 우, same locality, 23. vi. 1985 (R. Morakote).

Host : Unknown.

Distribution : Japan (Hokkaido, Honshu, Kyushu).

Remarks : This species can be distinguished from other species by having the bright yellow third antennal segment, and the pale pubescence and bristles on the body. This species seems to be closely related to V.villosa because the male genitalia and female ovipositor are almost similar to those of $\mathrm{V}$. villosa.

Verrallia japonica Morakote, sp. n.

\section{M ale.}

All body pubescence and bristles mostly black, except the tuft of long pubescence on lateral side of tergite 1 mixed with pale hairs anteriorly.

Head almost similar to that of V.pilosa but third antennal segment brownish yellow on anterior half.

Thorax and scutellum velvety black on dorsum, brownish pruinose, cinereous on notopleuron and pleurae ; scutellum with 4 very strong marginal bristles ; propleural fan and anepimeral pubescence black.

Legs with coxae, trochanters and femora black, with greyish dust ; all femora with a distinct wart beneath near middle ; tibiae almost black except base and tip 
brownish black ; tarsi dark brown; pulvilli bright yellow, about as long as last tarsal segment.

Wings hyaline, tinged with brown, stigma dark brown, extending back to tip of Sc, about twice as long as fourth costal section; r-m situated about middle of discal medial cell, last section of fourth vein Ml with a sign of kink at basal one-fifth.

Abdomen similar to that of $V$.pilosa but differs as follows : sternite 5 with only two short tack-like black spines on each side near posterior margin.

Genitalia (Fig. 16D and F) : Differing from those of congeneric species as follows : paramere without any spine, almost as long as aedeagus, with membranous sheath apically; aedeagus with a bifid apical plate-like process posteromedially.

Length : Body $4.5 \mathrm{~mm}$; wing $4.5 \mathrm{~mm}$.

\section{F emale.}

Quite similar to the female of V.pilosa but different as follows: third antenna1 segment brownish yellow on anterior half; a wart beneath all femora more distinct than in pilosa; ovipositor (Fig. 17C) rather large in proportion to its abdomen ; piercer very thick at its base as seen from lateral, moderately upcurved; base of ovipositor globular, black with greyish dust.

Length : $4.5 \mathrm{~mm}$; wing $4.5 \mathrm{~mm}$.

Holotype: $\sigma^{7}$ (Type No. 2722, Kyushu Univ.), Kawaranobo, Mt. Hayachine, Iwate Pref., Honshu, 15. vii. 1985 (R. Morakote).

Paratypes: 16, Mt. Sanageyama, Toyota, Aichi Pref., Honshu, 18. vi. 1972 (T. Tanaka); 1 우, same data as holotype.

Host : Unknown.

Distribution : Japan (Honshu).

Remarks : This species is distinguished from other species by having the third antenna1 segment tinged with brownish yellow on the anterior half and the abdominal sternite 5 with two short tack-like spines on each side near posterior margin. 


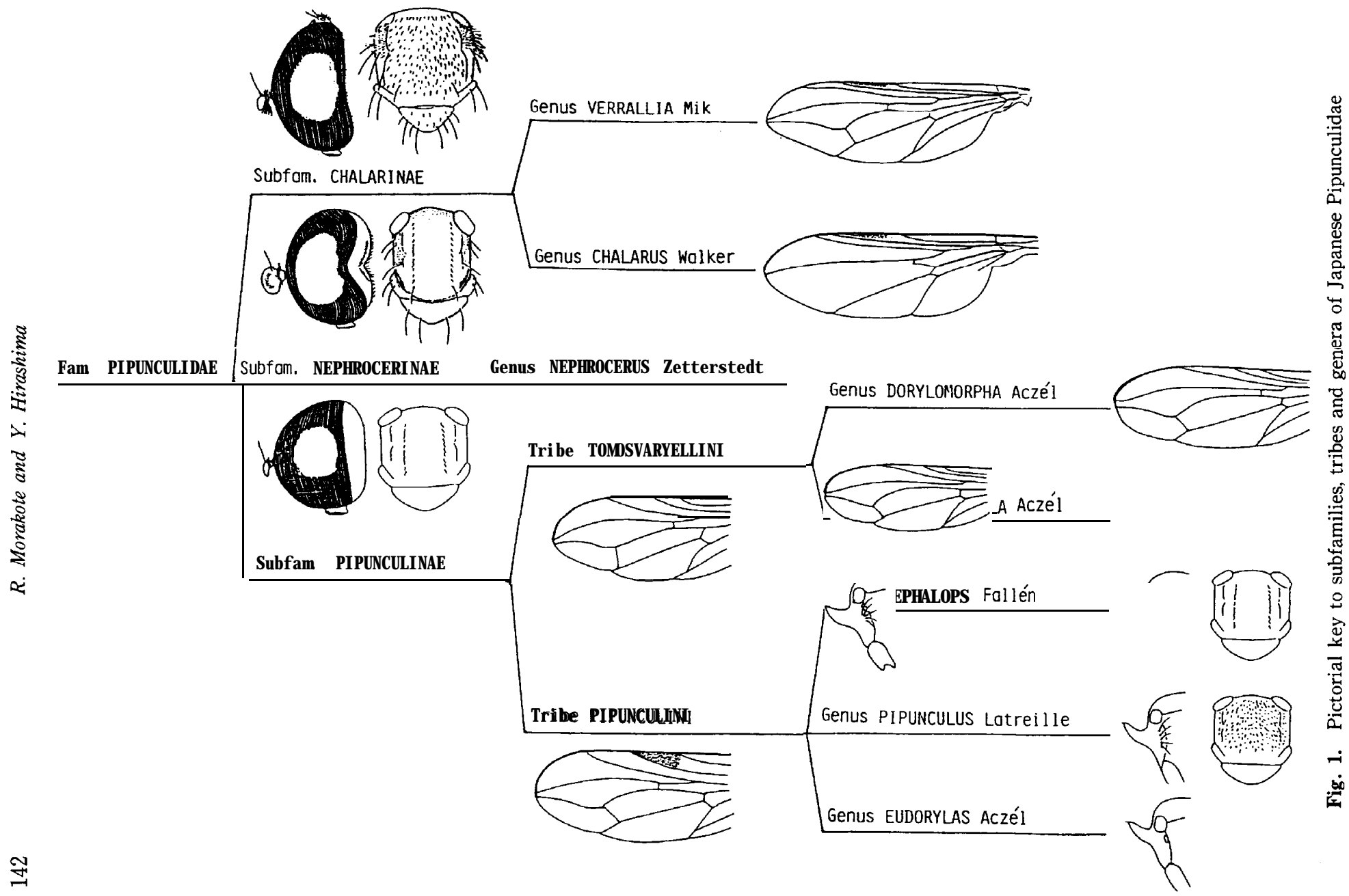




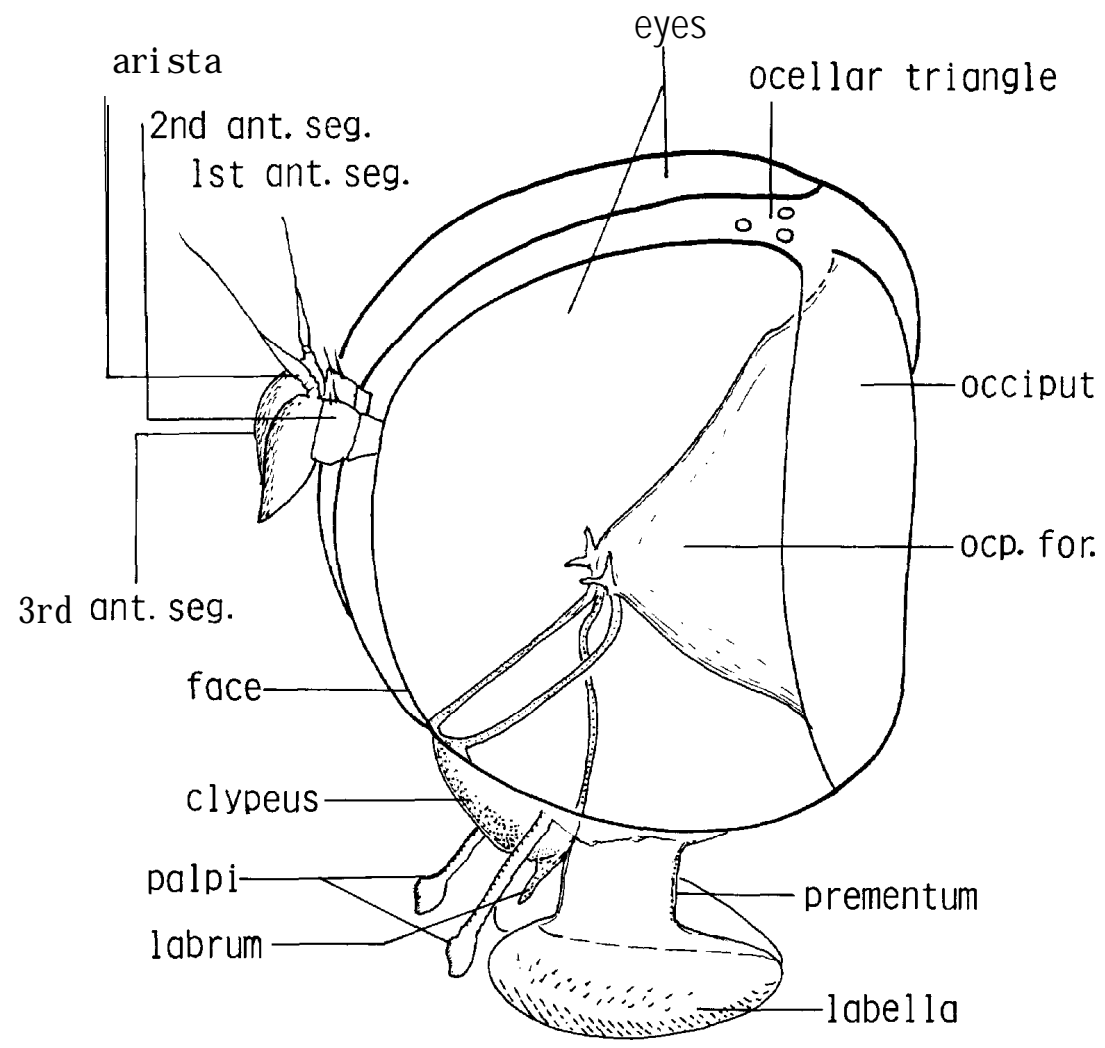

Fig. 2. Female head of Cephalops annulipes (Zetterstedt), lateral view. (ant. seg.= antennal segment, ocp. for $=$ occipital foramen) 

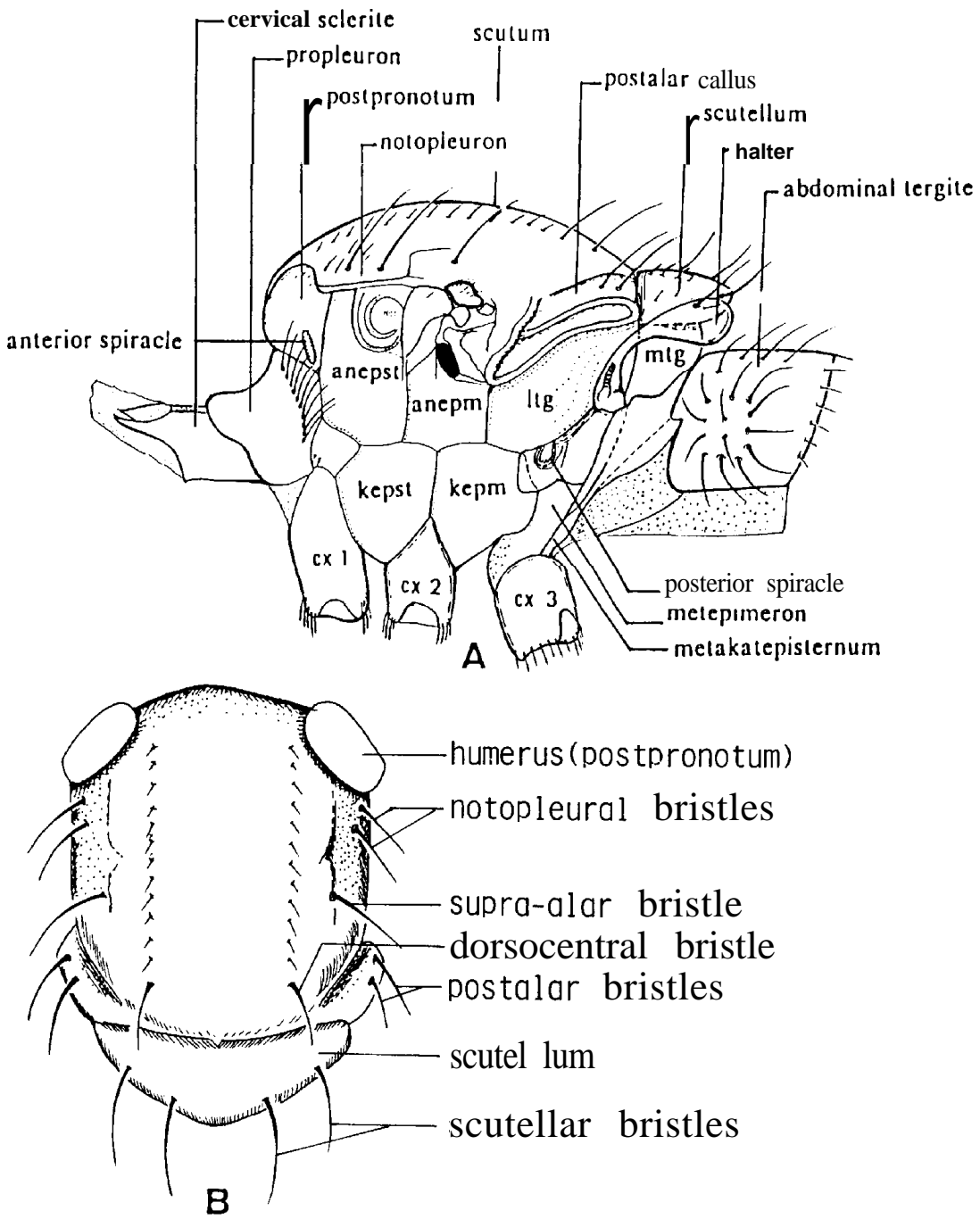

Fig. 3. Thorax of Nephrocerus grandis Morakote : A. Lateral view ; B. dorsal view. $(\mathrm{cx}=\mathrm{coxa}, \quad$ anepst $=$ anepisternum,$\quad$ anepm $=$ anepimeron,$\quad$ kepst $=$ kataepisternum, kepm = kataepimeron, ltg=laterotergite, $\mathrm{mtg}=$ metatergite) 


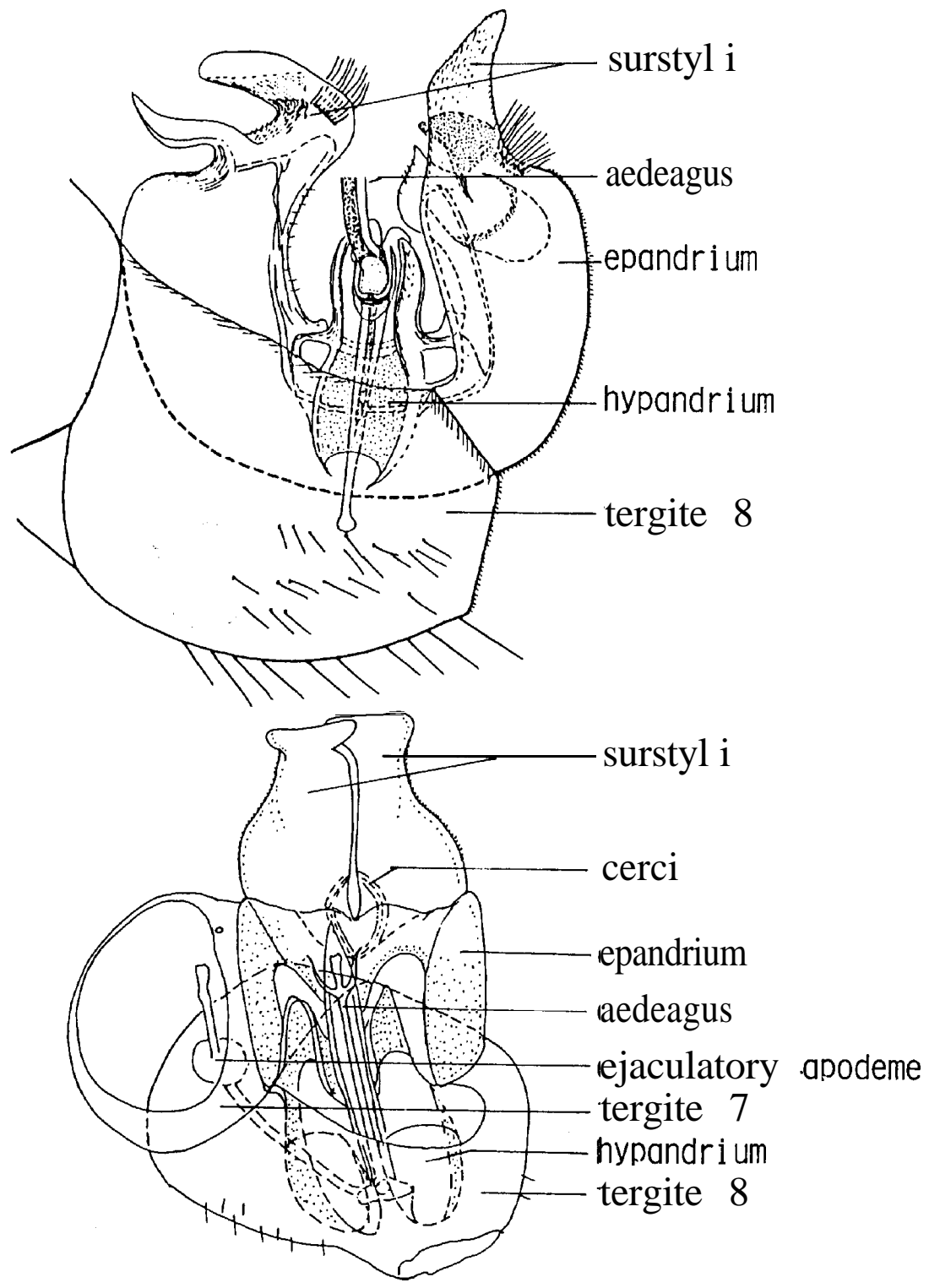

Fig. 4. Male genitalia : A. Nephrocerus grandis Morakote, ventral view ; B. Cephalops kumatai Morakote, sp. n. (in press), ventral view. 


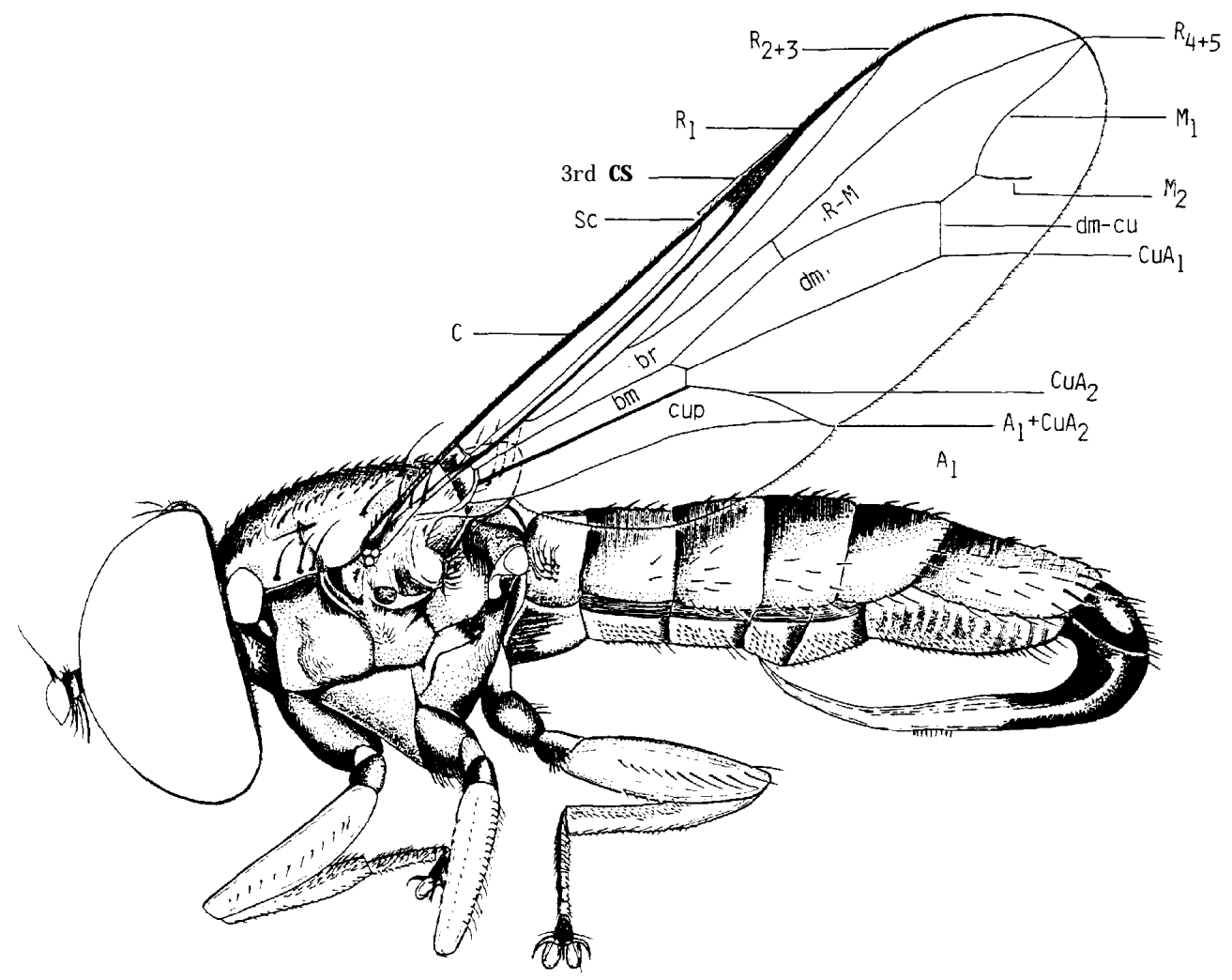

Fig. 5. Verrallia spectabilis Collin (female), with terminology of wing vein. (A1, A2= branches of anal veins, $\mathrm{C}=$ costa, $\mathrm{Cu}=$ cubitus, $\mathrm{CuA1}, \mathrm{CuA} 2=$ branches of cubitus, $\mathrm{Ml}$, $\mathrm{M} 2=$ branches of media $(\mathrm{M}), \mathrm{R} 1, \mathrm{R} 2+3, \mathrm{R} 4+5=$ branches of radial $(\mathrm{R}), \mathrm{Sc}=$ subcosta, 3rd $\mathrm{CS}=$ third costal section, br $=$ basal radial cell, $\mathrm{bm}=$ basal medial cell, cup $=$ posterior cubital cell, dm=discal medial cell, dm-cu=discal medial cubital cross vein, $\mathrm{R}-$ $\mathrm{M}=$ radial cross vein 

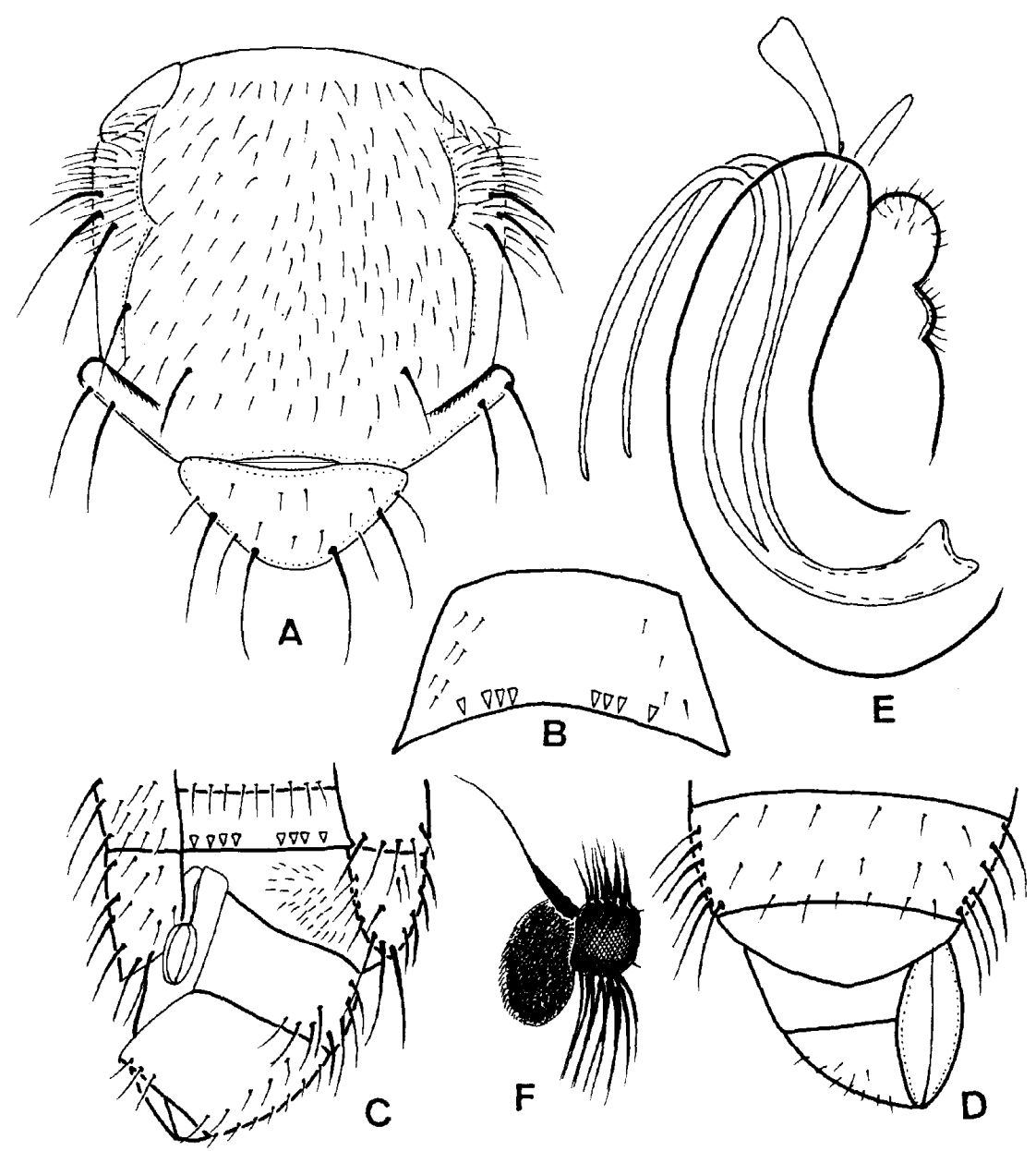

Fig. 6. Verrallia rebunensis Morakote, sp. n. (male) : A. Thorax, dorsal ; B. stemite 5 ; C. abdominal terminalia, ventral ; D. ditto, dorsal ; E. genitalia, lateral ; F. antenna. 


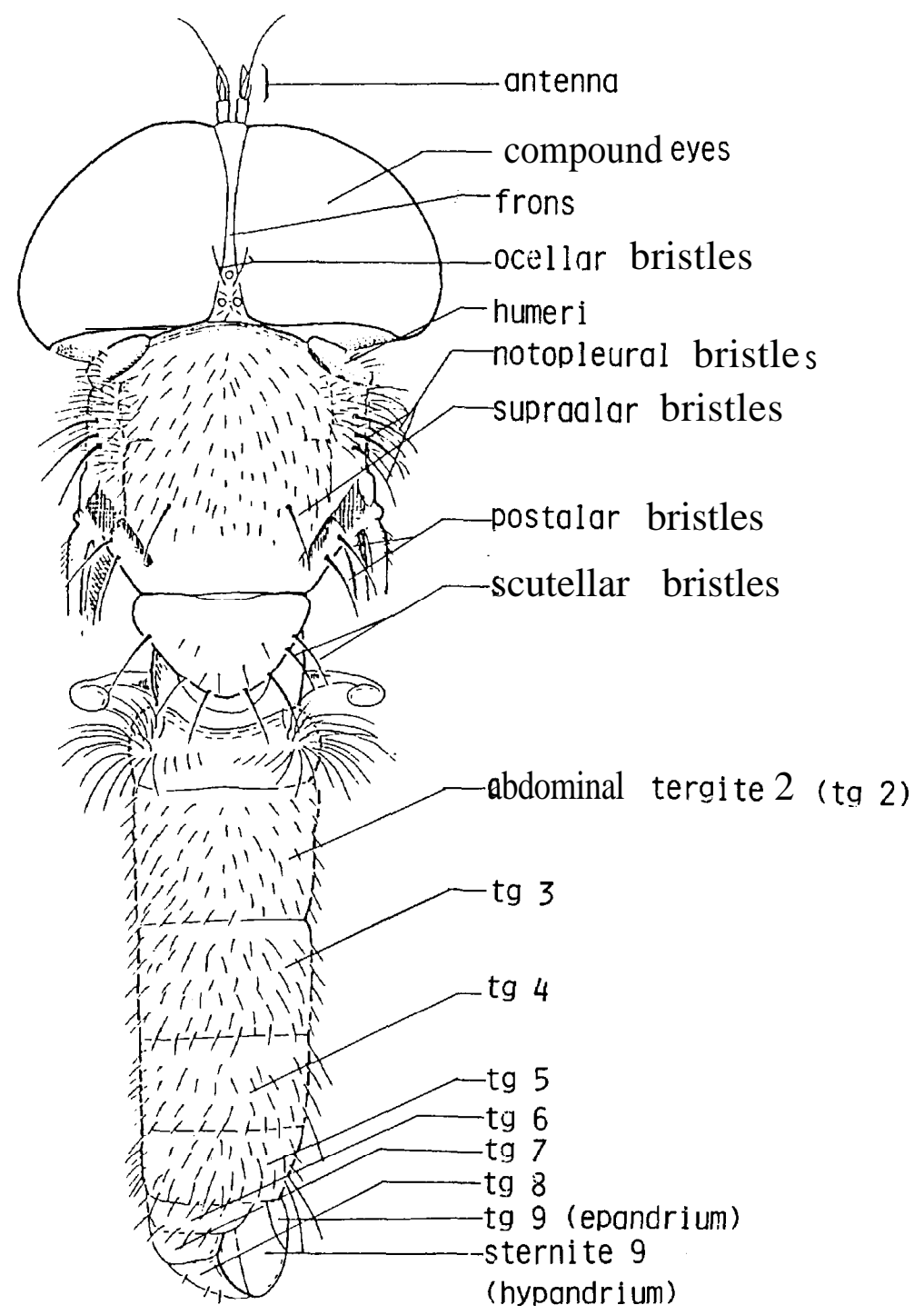

Fig. 7. Verrallia pala Morakote, sp. n. (male). 


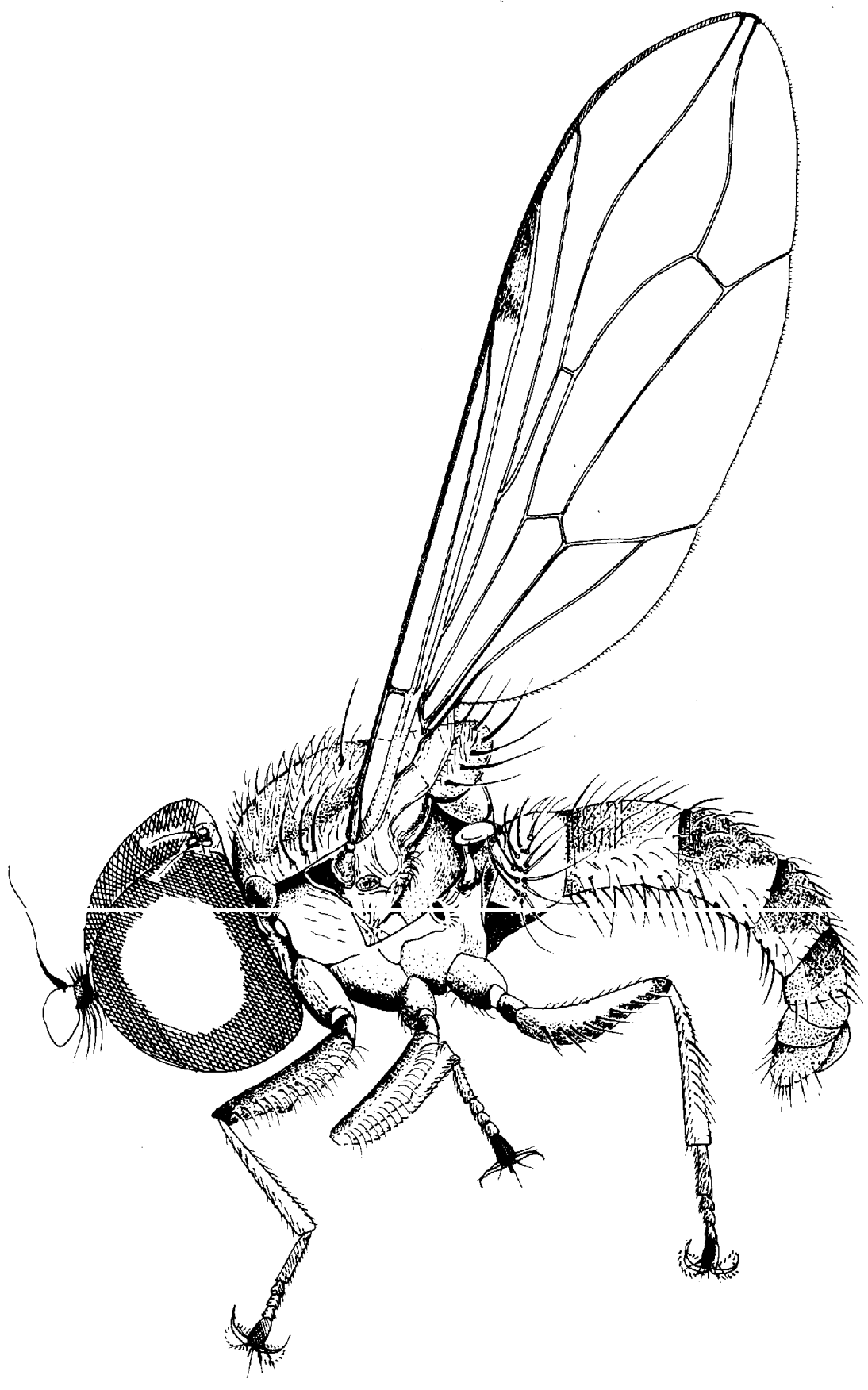

Fig. 8. Verrallia pala Morakote, sp. n. (male). 


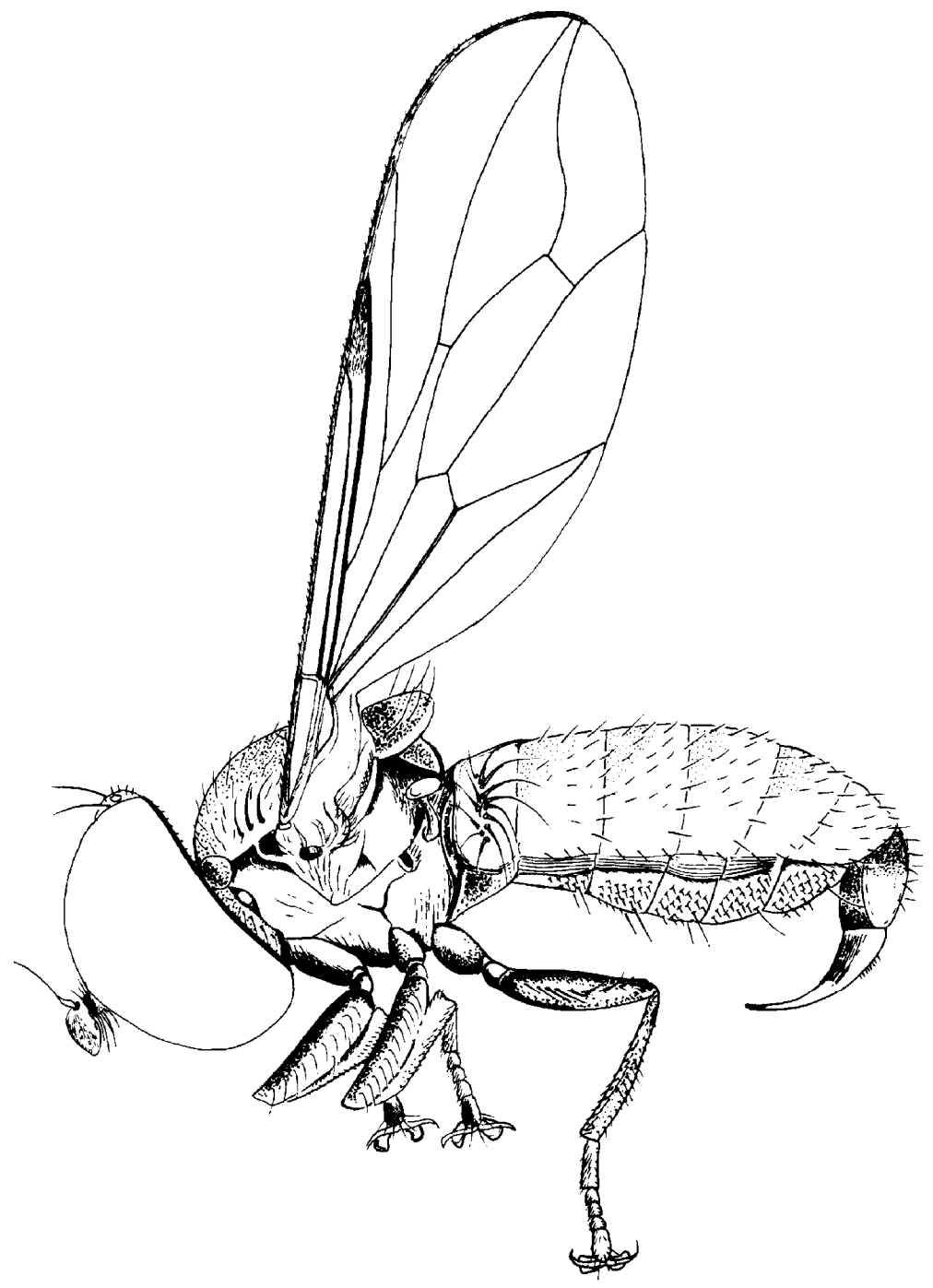

Fig. 9. Verrallia pala Morakote, sp. n. (female). 


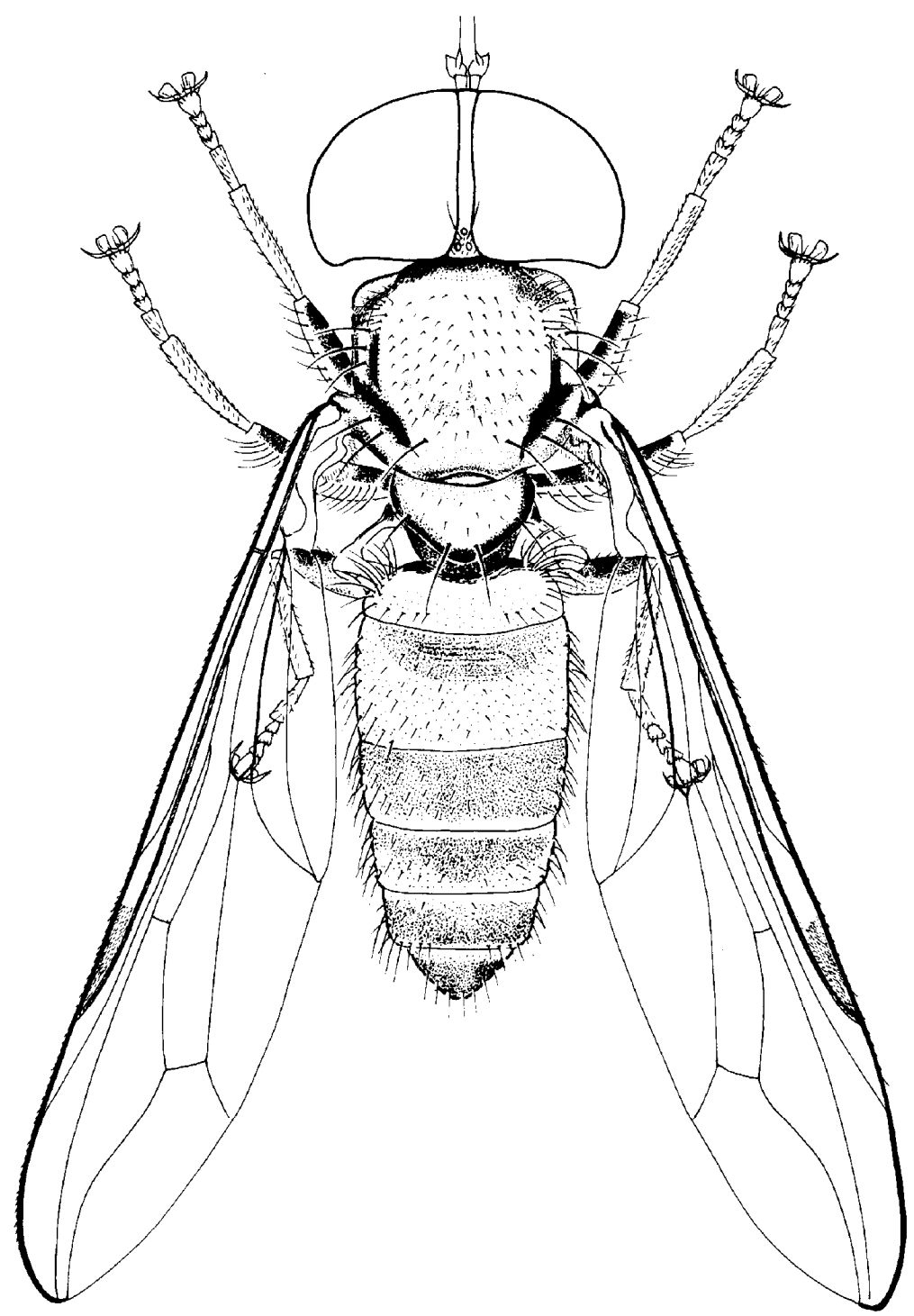

Fig. 10. Verrallia japonica Morakote, sp. n. (female). 


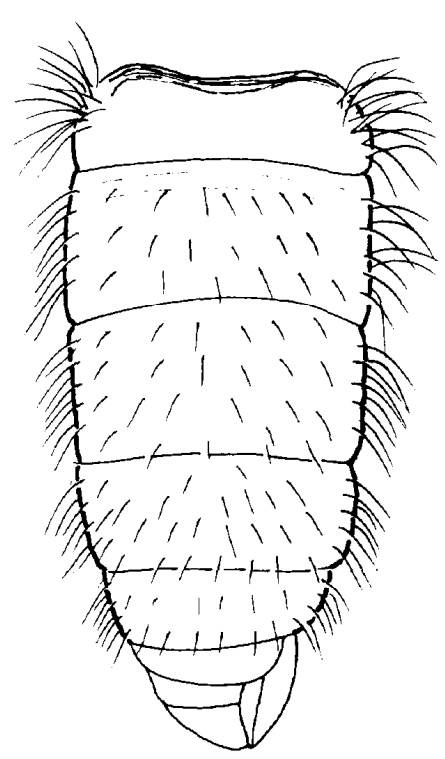

A

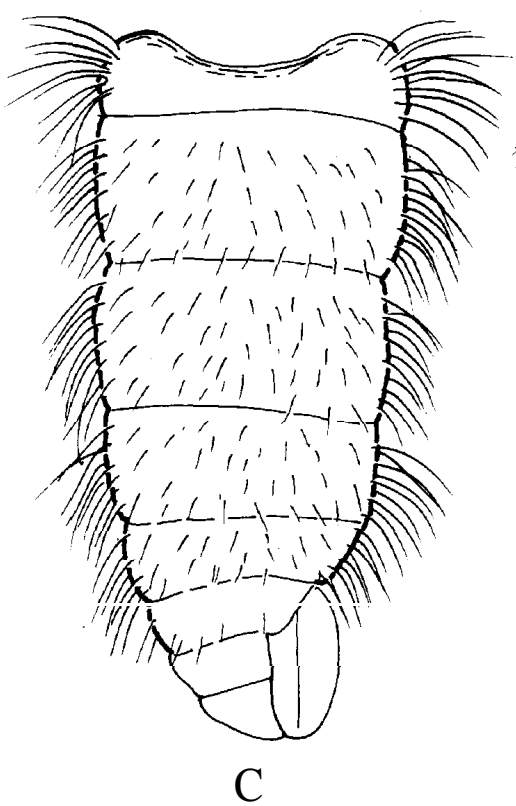

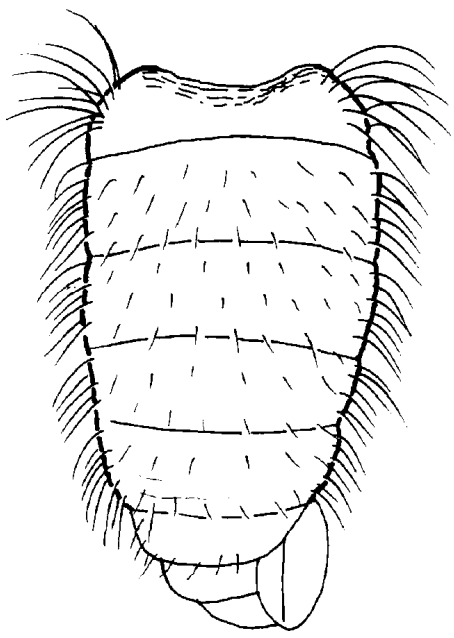

B

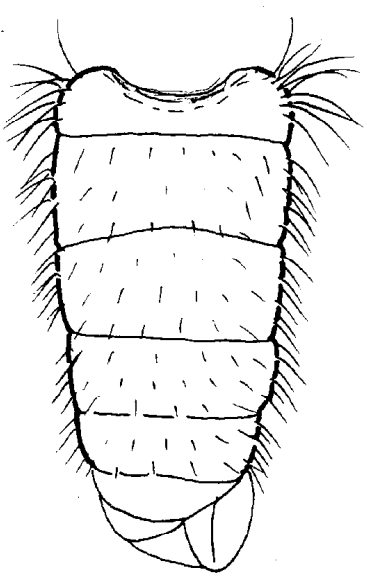

D

Fig. 11. Male abdomen of Verrallia spp., dorsal view : A. villosa (von Roser), B. pilosa (Zetterstedt), C. setosa Verrall, D. beatricis Coe 


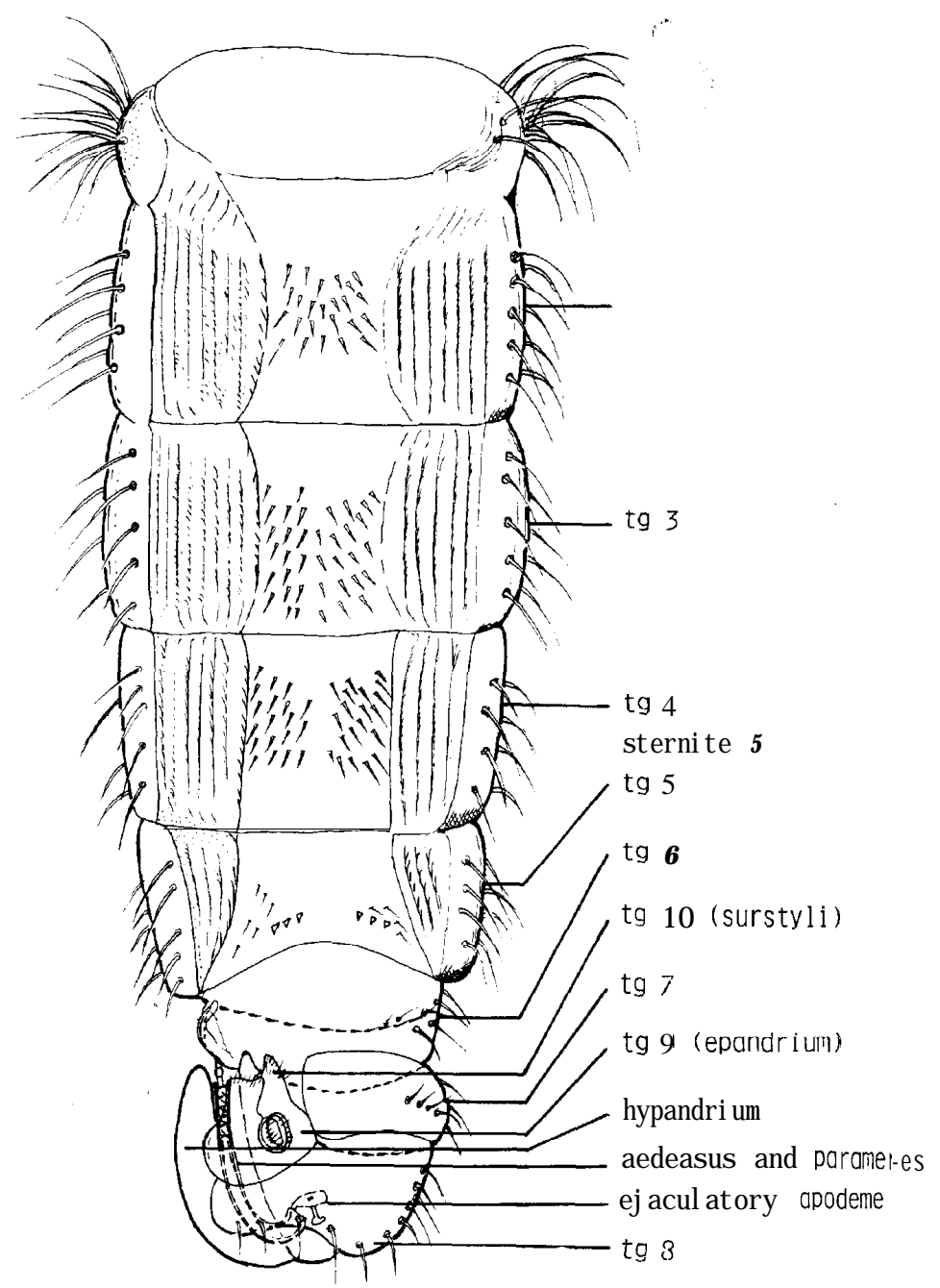

Fig. 12. Male abdomen of Verrallia pala Morakote, sp. n., ventral view. 

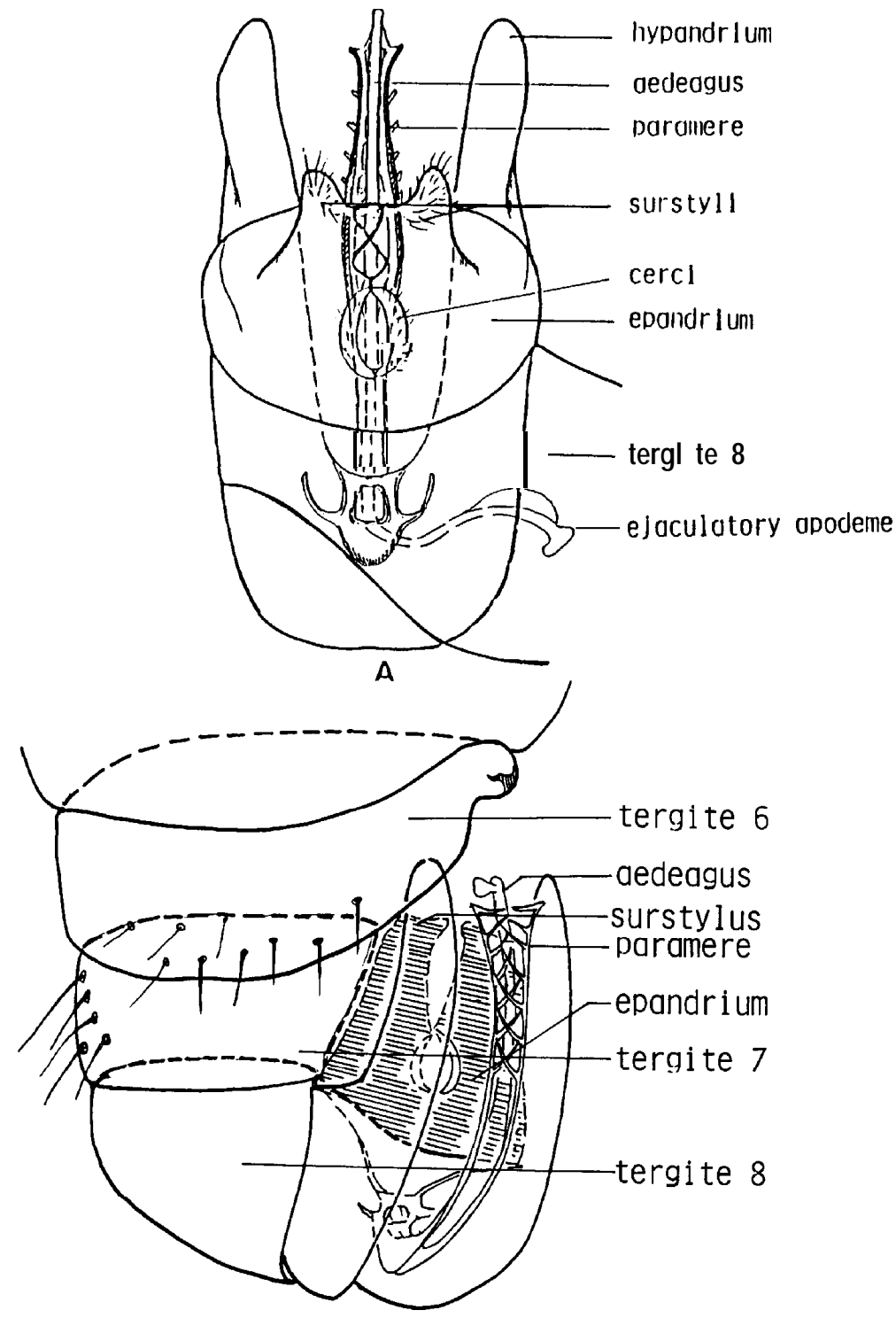

B

Fig. 13. Male genitalia of Verrallia pala Morakote, sp. n. : A. dorsodistal view, B. ventral view. 

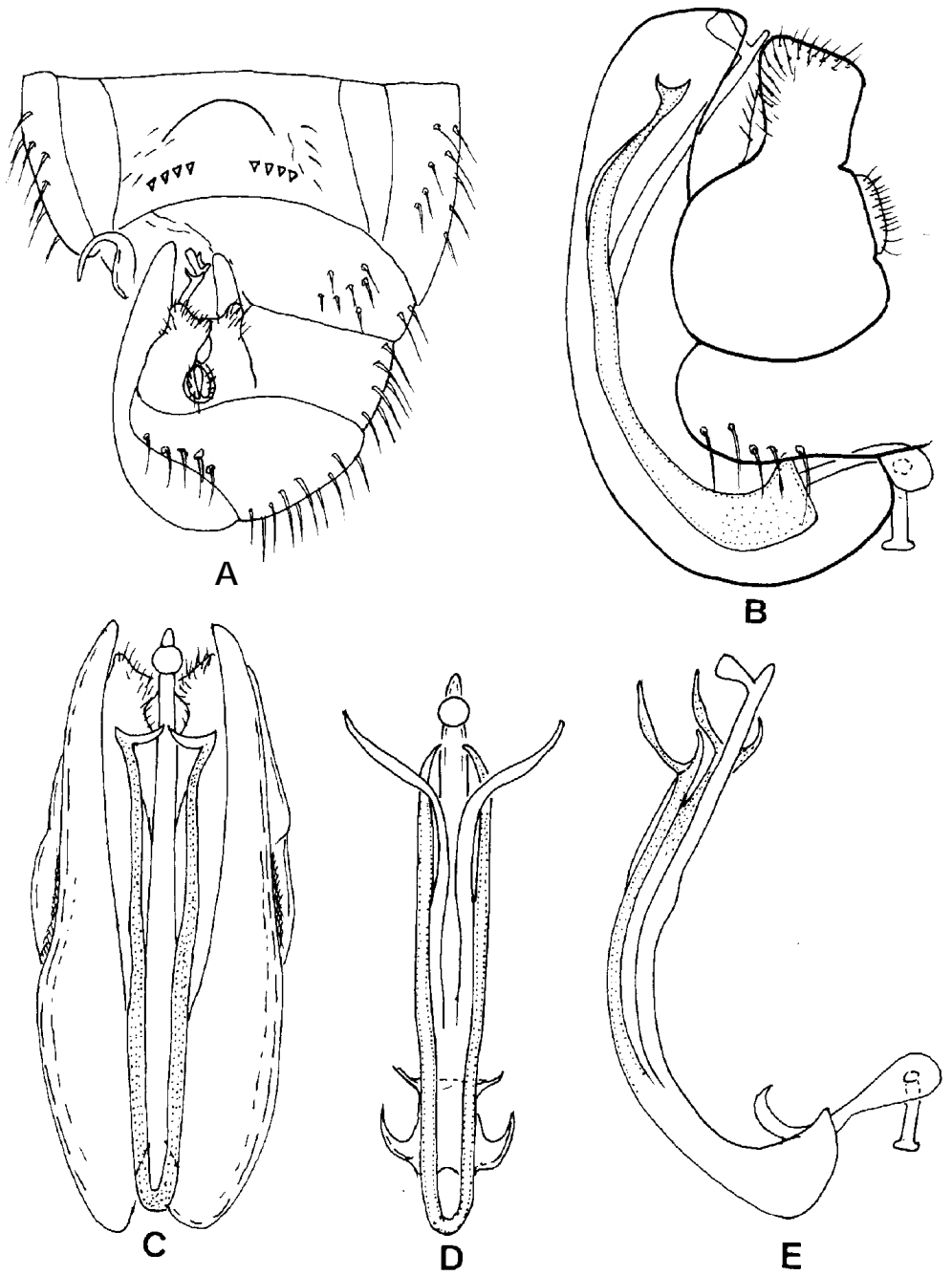

Fig. 14. A-C.Verrallia pilosa (Zetterstedt) (male) : A. Abdominal terminalia, ventral ; B. genitalia, lateral ; C. ditto, dorsal. D and E. aedeagus and parameres of $V$. beatricis Coe; D. dorsal ; E., lateral. 

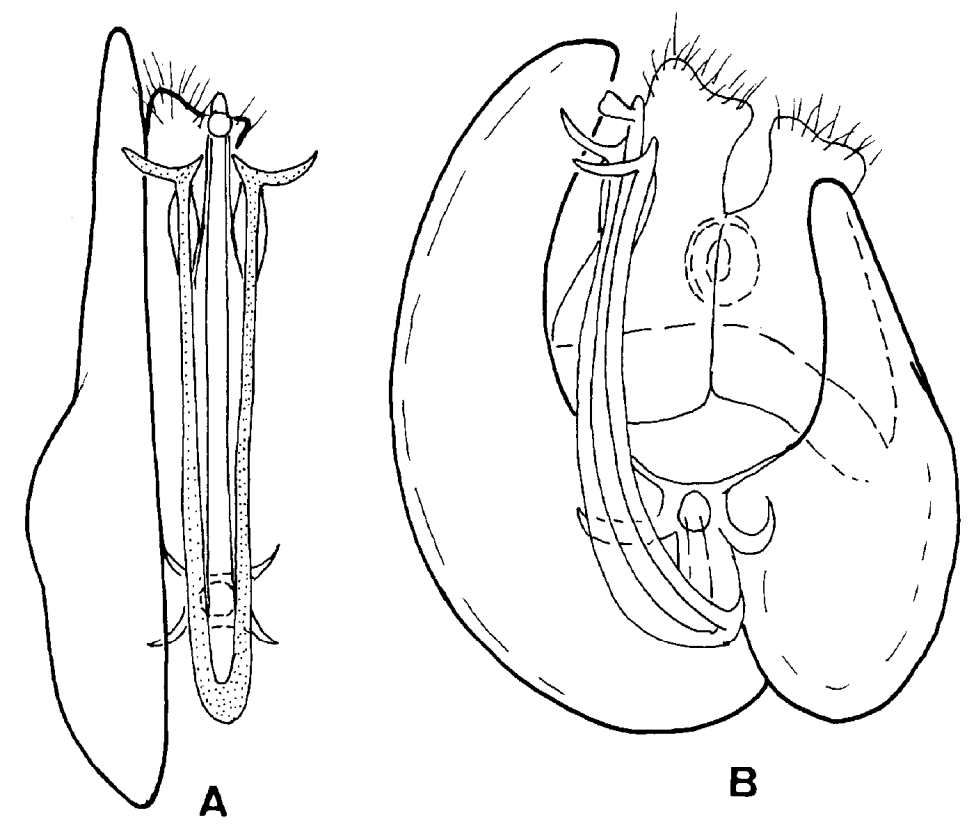

B
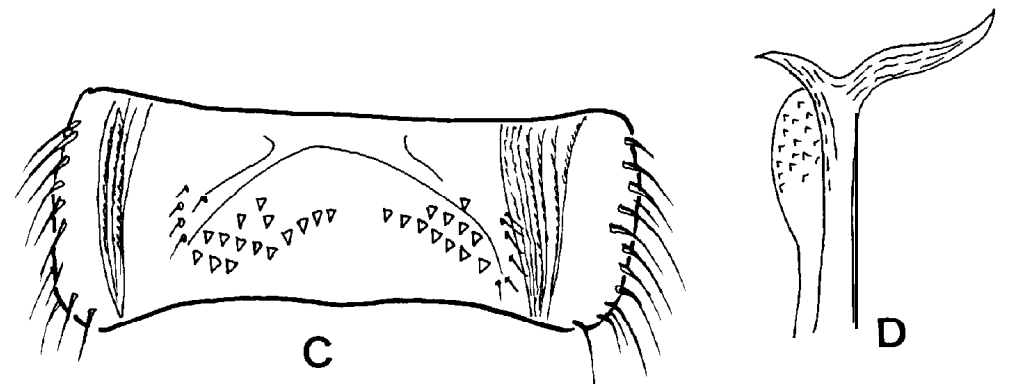

Fig. 15. Verrallia setosa Verrall (male) : A. Genitalia, dorsal ; B. ditto, dorsolateral ; C. sternite 5, ventral ; D. apex of paramere. 


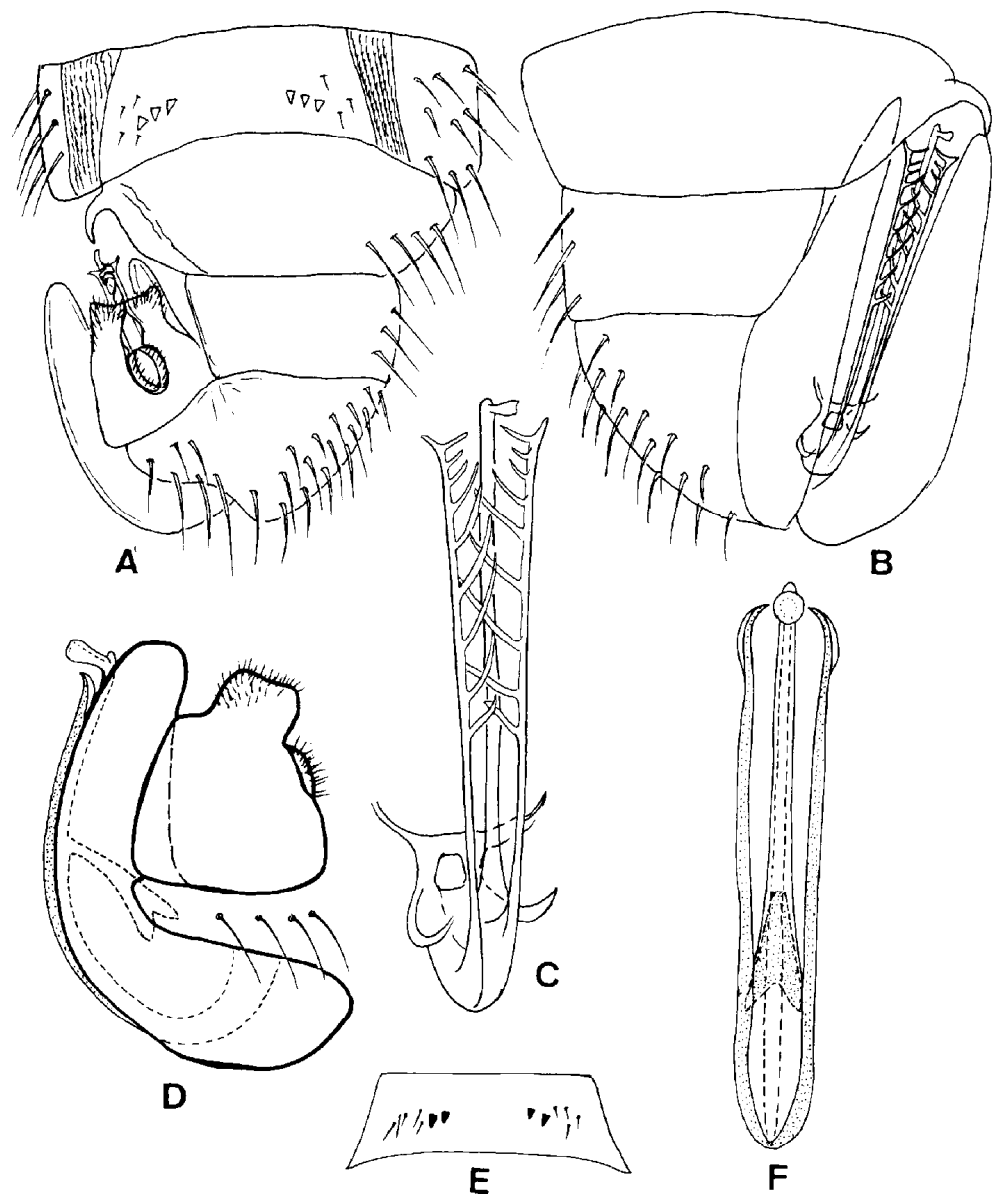

Fig. 16. A-C. Verrallia villosa (von Roser), male: A. Abdominal terminalia, ventral ; B. ditto, dorsal ; C. aedeagus and parameres, dorsal. D-F. V. japonica Morakote, sp. n. :

D. genitalia, lateral ; E. sternite 5 ; F. aedeagus and parameres, dorsal. 

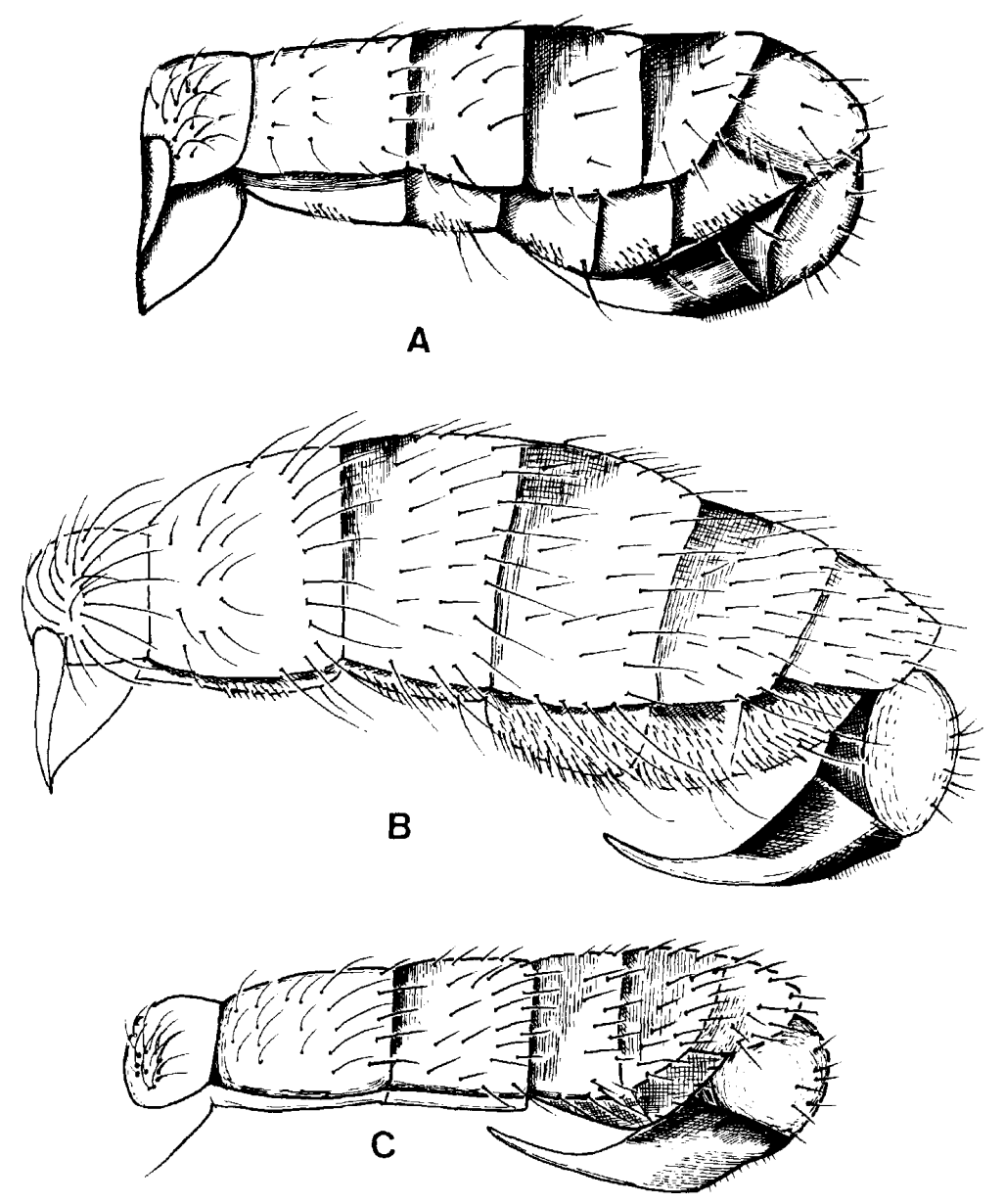

Fig. 17. Female abdomen of Verrallia spp., lateral : A. villosa (von Roser) ; B. pala Morakote, sp. n. ; C. japonica Morakote, sp. n. 

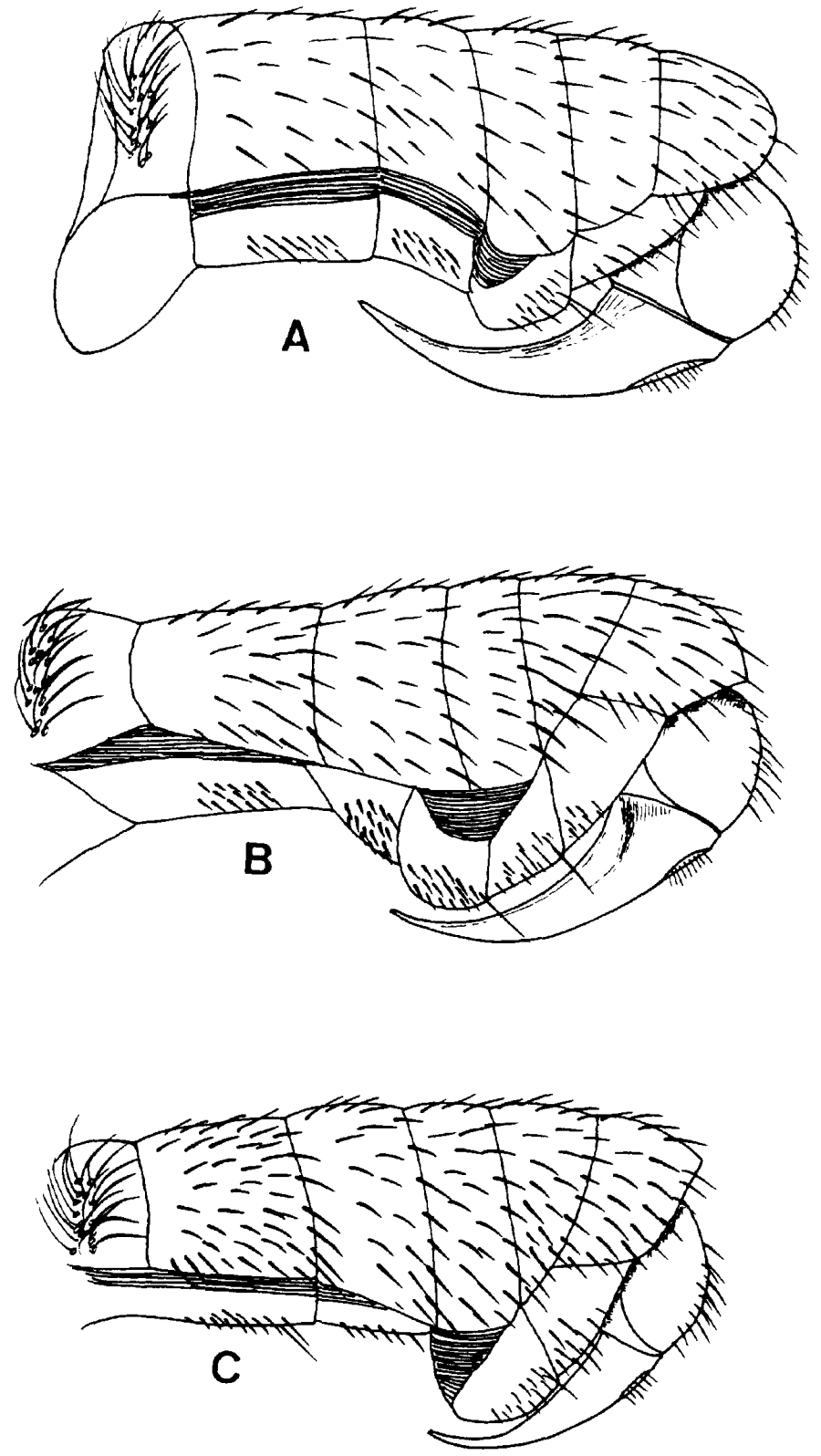

Fig. 18. Female abdomen of Verrallia spp., lateral : A. pilosa (Zetterstedt) ; B. setosa Verrall ; C. beatricis Coe. 